\title{
Corporate Governance and Pension Fund Performance
}

\author{
Oskar Kowalewski ${ }^{1}$
}

ABSTRACT

\begin{abstract}
This study provides new evidence on the impact of governance on the performance of privately defined contribution pension plans. Using a hand collected data set on governance factors, the study shows that the external and internal governance mechanisms in pension plans are weak. One explanation for this weakness is the potential conflict between the pension beneficiaries and the fund's owner, which depends on who bears the investment risk in the pension plan. Hence, different governance factors are found to be important for pension fund return on invested assets and also for its economic performance. Consequently, the overall policy conclusion is that more focus should be put on the governance of the pension funds, taking into account the different interests of the beneficiaries and owners as it may determine their performance.
\end{abstract}

KEY WORDS: pension funds, corporate governance, agency theory, performance

JEL Classification: $\quad$ G23, G28, G30

${ }^{1}$ Warsaw School of Economics, POLAND

\section{Introduction}

As a result of the current crisis in the OECD countries, the losses of pension funds are estimated to be $\$ 5.4$ trillion or about $20 \%$ of the value of assets in 2008 (Antolín \& Stewart, 2009). Consequently, in a large number of countries policy makers are again paying attention to how private pension funds are managed (Rudolph et al., 2010) and taking into consideration different reforms that may dramatically change the pension system in some countries. ${ }^{1}$ The goal of this reform is often to increase investment returns of pension funds and, consequently, their asset value. However, little attention has been paid thus far to the pension funds' governance structures and whether they may have an impact on their performance. The main purpose of this study is to address this issue and analyze

!

Corespondence concerning to this article should be addressed to: okowale@sgh.waw.pl whether governance issues affect the performance of the pension funds.

Over the last decades, various scholars have found positive associations between better corporate governance and firm market value and performance. ${ }^{2}$ Surprisingly, the impact of the governance structures in privately managed pension funds' on its performance has received little attention in the empirical research. In contrast, Besley and Prat (2003) used a theoretical model to show that governance structure matters in defined benefit (DB) and defined contribution (DC) pension plans with respect to three potential sources of agency problems: the responsibility for monitoring the asset manager, asset allocation decisions, and the plan's level of funding.

The two types of pension plans differ from each other, and the Besley and Prat (2003) model presents the different ways that the funds should be governed. In a $\mathrm{DB}$ plan, the beneficiary is given a set retirement benefits based on a formula that considers years of sal- 

forming fund might leave it for a competitor, which in a competitive market should discipline its management. While the research on mutual funds has confirmed the significance of markets as external controls (Sirri \& Tufano, 1998), it has not confirmed the same for pension funds (Kominek, 2006; Cronqvist \& Thaler, 2004).

However, Gillan et al. (2006) found that the external and internal governance mechanisms were substitutes. For pension funds in which the external governance (as indicated by the flow of pension members) is weak, internal governance should be more important. Furthermore, Brown and Caylor (2004) found that an internal governance factor such as board characteristics were more associated with good firm performance than most external factors. The importance of board composition was also emphasized by Besley and Prat (2003), who documented that in pension funds the conflicts of agency differ from other companies, as there is no problem with separation of ownership and control. With pension funds it is rather more important to establish who bears the risk. In DC pension plans, the beneficiaries bear the risk, as they suffer from the poor investment performance of the funds. For that reason, they should have a strong impact on the body in charge of monitoring these funds. In other words, the board of directors for pension funds should include a proportion of outside directors who will represent the beneficiaries. In practice, however, directors are in most cases elected by the fund's owner, which may decrease their independence. ${ }^{3}$ Hence, the number of outsiders does not need to be positively related to the fund investment return and, therefore, other governance factors may be important, too.

In the literature, board size and board composition often constitute prevalent corporate governance issues. Small board size is believed to improve firm performance because the benefit of increased monitoring that comes with larger boards is outweighed by the poorer communication and decision making of larger groups (Jensen, 1993). Consistent with this notion, Yermack (1996) documented an inverse relationship between board size and profitability, asset utilization, and Tobin's Q.

Other board characteristics that were found to be important in the literature were diversity measured by gender (Carter et al., 2003), nationality (Masulis et al., 2010), the proportion of independent directors over the age of 69 (Core et al., 1999), and the num- ber of external appointments held by directors (Ferris et al., 2003) and their political connections (Agrawal \& Knoeber, 2001). In addition, Kim and Lim (2010) recently showed that the education level and the profession of outside directors may determine the firm's valuation, too.

Based on these studies, it can be hypothesized that the diversity of the outside directors may predict pension fund performance. In their model, Besley and Prat (2003) show that the ideal DC pension plans should use self-motivated members to monitor the funds. Hence, it is expected that age, which is a proxy for self-motivation, may be an important factor and positively related to the return on pension fund assets. In contrast, a large number of company insiders or foreigners on the board may have a negative impact on the fund's assets returns. At the same time, having outside directors with backgrounds in politics or law may be beneficial for the pension fund's performance (Faccio, 2006).

A method to analyze the effectiveness of the existing internal governance mechanisms is to examine the management and supervisory board member turnover. The underlying assumption is that governance can be considered to be more effective if the likelihood of management and board member turnover increases in pension funds with lower investment or/and economic performance. Studies that document a negative relationship between likelihood of turnover and a firm's performance include Warner et al. (1988) for the US, Kaplan (1994) for Japan and US, or Franks et al. (2001) for the UK. Kaplan and Minton (1994) show that this mechanism also holds true for chairmen of the board in German companies where a two-tier board model exists. Moreover, Jenter and Lewellen (2010) have recently provided new evidence on the disciplinary role of an underlying threat of dismissal as an incentive for managers, a theory that has been previously questioned by Denis and Denis (1995). Consequently, it may be expected that should pension funds be well governed, managers and board turnover will be negatively related to pension funds performance. In other words, the turnover of managers and board members might be used as a proxy for the performance of an internal governance mechanism.

Other firm characteristics have been employed in the literature to measure governance mechanisms, some of which can also be employed in the analysis of pension 

especially those commercial ones, are weak predictors of firm's future performance (Daines et al., 2010). One explanation offered is that CG indices were often driven by single factors, which they include. Indeed, Bhagat et al. (2008), reviewing a large number of CG indices, conclude that often one variable is a better predictor of performance than the quality of a firm's governance.

Consequently, it may be expected that the CG indices will be a poor predictor of a pension fund's governance, as they will be influenced by a particular factor that will be included based on the empirical results in this study. Moreover, as different indices will be combined later on, their predictive power should decline because the single factors will receive less weight. Hence, I expect to confirm that there is no single best measure of effective governance, as it depends on context and the firm's specific circumstances (Bhagat et al., 2008; Adams et al., 2010).

\section{The institutional setting}

Since the 1990s, the World Bank has promoted a threepillar pension system across the world (World Bank, 1994). The model separates the major objectives of social security into three pillars, each with its own source of funding. The first pillar provides social safety net support to everyone and, thus, should ideally be a publicly managed, mandated, unfunded DB pension system. The second pillar emphasizes savings and provides the most benefits to those who contribute the most. Hence, the system should be also mandated but consist of a privately managed, funded DC pension system. The third pillar encourages discretionary savings and is available to anyone who cares to supplement the retirement income provided by the first two pillars, in which case it might be either a privately or publicly managed pension system.

While, the model has been introduced in more than 80 countries, only a few of them would qualify today as having a multi-pillar scheme such as that proposed originally by the World Bank (Andrews, 2006). Consequently, today there are many combinations of the original elements, yet most of them include a privately managed DC pension system. Furthermore, it is expected that more and more countries will move from a DB model to various types of DC pension systems, either publicly or privately managed, as a result of the aging population and the severe constraints on public budgets following the current crisis.
In Poland, the three-pillar pension system was introduced in 1999. The first pillar is a reformed pay-asyou-go system and is managed by a state-owned entity. The second pillar consists of open pension funds (OPFs) and is managed by private managing companies (PTEs). The third pillar consists of employer sponsored pension plans as well as individual pension savings programs. All of the pillars are based on DC plans; the two first are compulsory and the third is voluntary, which may explain its underdevelopment. The private pension fund sector is regulated by the Financial Supervision Authority (FSA).

As a testing ground, I use the OPFs, which are managed by private PTEs. At the beginning of the pension reform, 21 PTEs were set up mainly by foreign-owned banks or insurance companies. The market share of the newly created pension funds was unequal from the beginning due to different distribution channels and the market power of the founders. As a consequence, a consolidation process among the smaller PTEs began only two years after initiation of the pension reform and the number of funds decreased to 14 in 2010. By that time those PTEs were managing through the OPFs close to 15 million individual pension accounts, while their assets constituted around 16\% of GDP. Furthermore, the number of members and OFEs assets will further grow as only employees born in 1969 and after had to join the new system. Employees born between 1949 and 1969 were given a choice either to join the multi-pillar pension system or stay in the old pay-as-you-go pension system. All of the remaining employees remained in the old pension system. As a result, the number of OFEs members and their assets will grow till 2050. At this time, all workers should be covered by the new pension system, while it is assumed that by then the pension fund will be the biggest financial institution measured by assets in Poland (Kowalewski, 2008).

In the last decade, the consolidation process in the pension industry was induced by the small scale of some of the OFEs. The OFEs do not guaranteed profitability for the PTEs, as over $90 \%$ of their revenue depends on the value of managed assets and the number of members. In 2010, the fee for managing the assets contributed on average to $45 \%$ of revenue for PTE, while the up-front fee from members contributed to $39 \%$. It is expected that in the future the fee for managing the assets will be the dominant source of revenue 

influenced by the losses from the start-up phase.

Additionally, DOA and DOE are calculated as an alternative measure for economic performance. These variables were calculated as dividend payouts divided by total assets or equity of the pension fund firm (PTE), respectively. As dividend policy is often associated with good governance, it may be expected that the same factors are important for ROA (ROE) as for the DOA (DOE). Detailed definitions of all the variables used in the study are given in Table 1.

Table 1 also presents the summary statistics of the key financial and governance variables of pension funds in the sample. The average pension unit return is above $10 \%$, while, conversely, ROE or ROA is around $-24 \%$ or $-25 \%$. All of the performance variables show a large variation across the period. Return on the pension units and the Sharp ratio variation are mainly attributed to the changes in the stock market prices, while the negative profitability of the pension funds is due to large start-up investments in the first years. As a result of those investments, all of the funds reported negative financial results until 2001, which did have an effect on their equity.

The size of the supervisory board (management) is measured with the variables Bsize (Msize). Additionally, a ratio $M / B$ size is employed as a proxy for potential inefficiencies in monitoring, as the number of board members increases relative to management. In fact, the ratio shows large fluctuations, while its average is 0.5 . In the study, the following variables control for the board diversity and composition: age, women, foreigners, former managers, and outsiders. Managers or board members employed or related to any of the pension fund shareholders are considered to be insiders, while those who are not are outsiders. According to this definition, inside directors represent about $66 \%$ of the board, which is higher than the legal threshold. The differences can be caused by two factors. First, a narrower definition is used in the study than in legal definitions. Second, as each manager and board member needs to be approved by the FSA, there are often vacancies for a longer time period.

As education may determine the behavior of managers and board members, we incorporate two measures for educational background, namely: law and economics. Moreover, we divide the outside directors into seven categories according to their present profes- sion. Finally, I checked whether outsider directors are sitting on boards of other companies, have interlocked relationship with other board members or managers, and, finally, if they have had any kind of political connections in the past.

As shown in Table 1, outsiders represent about $44 \%$ of the total board members. The average age of the outside directors is 54 years old, while for all members it is 49 years. Over $50 \%$ of the outsiders have a degree in economics, while $33 \%$ have a degree in law. Most of the outsiders are employed at academic institutions, while only $6 \%$ are working in the financial sector. The results are similar to the findings of Mayners Report (2001), who has shown that many trustees do not have in-depth knowledge of investments and are dependent on advisers in the UK. In fact, he reported that $62 \%$ of trustees have no professional qualifications in finance or investments, and $49 \%$ of them spend three hours or fewer when preparing for pension investment matters.

Moreover, the summary statistics show that in $70 \%$ of the boards at least one outsider is interlocked, while in $50 \%$ at least one is sitting on other boards or has political connections. Those results may indicate problems with the outside directors, as Bebchuk and Cohen (2005) suggest that staggered and busy boards are associated with weak governance and entrenched management.

As ownership may have an impact on corporate governance, we control for ownership as well as for the number of shareholders, which also has been found to be important. The results show that the majority of the pension funds are controlled by foreign companies, but, at the same time, most of them have more than one shareholder. In 2010, however, in only three pension funds were there at least two different shareholders, as in many cases the stronger shareholder bought out the remaining partner over the last decade.

To control for the pension fund activisms two measures are included. The first shows whether the pension fund incorporated a corporate governance code for its investment practices, in which it provided information on its goals and voting behavior. The second variable is a proxy for the fund's shareholder activisms, in which we use two proxies. The first shows the number of General Meetings (GM) scaled by the number of companies in the fund investment portfolio (GM no) where a pension fund representative was present. As in many cases, there were at least two GM of the same company; a sec- 
ond proxy shows the number of companies with a GM, for which the pension fund representative was present, which again is scaled by the number of companies in the fund's investment portfolio ( $G M c o$ ).

Other governance variables are auditor, which takes the value of one if there was a change in the external auditor, and zero otherwise. The PTEs and their managers' behavior are measured using three different variables. The first variable, ethics, is a dummy, which takes the value of one if the company has adopted some kind of ethics or internal governance code. The second variable shows the number of fines (fines no) that have been imposed on the PTE for breaking the law. As the regulator often imposes fines for negligence, another important indicator can be the value of fines (fines value): the higher its value the more likely it is connected to its investments policy and, hence, will affect the performance of the pension fund.
Finally, I use a number of control variables such as assets size and number of members. While assets size may have a negative impact on pension unit return, it can be positively related to the profitability of the pension fund measured by ROA (ROE) or DOA (DOE) due to economies of scale. In contrast, a large number of members may negatively affect pension fund profitability, as higher enrollment is related to more administrative costs while not having any affect on pension fund unit return. In addition, I include in some of the regressions variables to control for acquisitions, which takes the value of one if the pension fund acquired or merged with another entity. Finally, in the first regression we control for acquisitions and marketing costs, and use salaries as a proxy for number of employers when we investigate the changes in the number of members.

Table 1. Variables and descriptive statistics

\begin{tabular}{|c|c|c|c|c|c|c|}
\hline Variables & Description & Obs. & Mean & Std. & Min & Max \\
\hline \multicolumn{7}{|c|}{ Pension fund investment performance measures } \\
\hline Return & return on OPF unit & 194 & 0.10 & 0.08 & -0.18 & 0.30 \\
\hline Sharp & Sharp ratio for OPF unit & 180 & 0.45 & 1.27 & -2.64 & 2.43 \\
\hline \multicolumn{7}{|c|}{ Pension fund company performance measures } \\
\hline dMembers & annual changes in members & 173 & 0.10 & 0.33 & -0.21 & 3.60 \\
\hline ROE & profit before taxes to equity & 189 & -0.24 & 2.56 & -11.7 & 19.7 \\
\hline $\mathrm{ROA}$ & profit before taxes to assets & 189 & -0.25 & 0.97 & -5.68 & 0.58 \\
\hline DOE & dividend to equity & 189 & 0.06 & 0.13 & 0.00 & 0.74 \\
\hline DOA & dividend to assets & 189 & 0.05 & 0.11 & 0.00 & 0.62 \\
\hline \multicolumn{7}{|c|}{ Management and Board members turnover } \\
\hline CEO turnover & 1 if CEO dismissed and 0 otherwise & 194 & 0.27 & 0.44 & 0 & 1 \\
\hline M turnover & $\%$ of $\mathrm{M}$ dismissed to total $\mathrm{M}$ & 194 & 0.16 & 0.22 & 0 & 1 \\
\hline CB turnover & 1 if Chairman dismissed and 0 otherwise & 194 & 0.21 & 0.41 & 0 & 1 \\
\hline BM turnover & $\%$ of B members dismissed to total B & 194 & 0.16 & 0.23 & 0 & 1 \\
\hline \multicolumn{7}{|c|}{ Board Chairman (CB), Members (B) and Independent Board Members (BI) characteristics } \\
\hline BSize & number of B members & 194 & 6 & 2 & 3 & 11 \\
\hline M/BM size & number of $\mathrm{M}$ to $\mathrm{B}$ members & 194 & 0.51 & 0.21 & 0.06 & 1.67 \\
\hline BOutsiders & $\%$ of $B$ members who are independent & 194 & 0.44 & 0.15 & 0 & 0.80 \\
\hline BWoman & $\%$ of B members who are woman & 194 & 0.11 & 0.13 & 0 & 0.50 \\
\hline BForeigners & $\%$ of B members who are foreigners & 194 & 0.23 & 0.25 & 0 & 1 \\
\hline BFormer & 1 if former $\mathrm{M}$ on the board and 0 otherwise & 194 & 0.1 & 0.3 & 0 & 1 \\
\hline
\end{tabular}


Table 1. (continued)

\begin{tabular}{|c|c|c|c|c|c|c|}
\hline Variables & Description & Obs. & Mean & Std. & Min & Max \\
\hline \multicolumn{7}{|c|}{ Board Chairman (CB), Members (B) and Independent Board Members (BI) characteristics } \\
\hline BAge & average age of all the $B$ members & 194 & 49 & 5 & 36 & 61 \\
\hline CBIndependent & 1 if the CB is independent and 0 otherwise & 193 & 0.17 & 0.38 & 0 & 1 \\
\hline CBAge & $C B$ age in years & 194 & 47 & 7 & 31 & 64 \\
\hline CBTenure & CB tenure in years & 194 & 1.87 & 2.29 & 0 & 11 \\
\hline CBEconomist & 1 if the CB has economic education and 0 otherwise & 194 & 0.87 & 0.34 & 0 & 1 \\
\hline BIAge & Bls average age in years & 189 & 54.4 & 7.8 & 34 & 71 \\
\hline BITenure & Bls average tenure in years & 194 & 2.5 & 2.1 & 0 & 8 \\
\hline BIEconomy & $\%$ of Bls with economic education & 194 & 0.51 & 0.36 & 0 & 1 \\
\hline BILaw & $\%$ of Bls with legal education & 194 & 0.33 & 0.30 & 0 & 1 \\
\hline BIFinance & $\%$ of Bls who are in finance industry & 194 & 0.06 & 0.17 & 0 & 1 \\
\hline BIManager & $\%$ of Bls who are senior managers & 194 & 0.10 & 0.22 & 0 & 1 \\
\hline BIAccountant & $\%$ of Bls who are accountants & 194 & 0.02 & 0.12 & 0 & 1 \\
\hline BIAttorney & $\%$ of Bls who are attorneys & 194 & 0.15 & 0.26 & 0 & 1 \\
\hline BIConsultant & $\%$ of Bls who are consultants & 194 & 0.06 & 0.20 & 0 & 1 \\
\hline BIProfessor & $\%$ of Bls who are academics & 194 & 0.49 & 0.38 & 0 & 1 \\
\hline BIOther & $\%$ of Bls with other professions & 194 & 0.06 & 0.13 & 0 & 0.5 \\
\hline BlBoards & 1 if any of the Bls is sitting on boards of other companies & 194 & 0.53 & 0.50 & 0 & 1 \\
\hline BIPolitical & 1 if any of the Bls is/was political connected & 194 & 0.59 & 0.49 & 0 & 1 \\
\hline Bllnterlocked & 1 if any of the Bls is connected with other Bl outside the fund & 194 & 0.70 & 0.46 & 0 & 1 \\
\hline BlCriminal & 1 if any of the Bls is/was accused of any kind of crime & 194 & 0.05 & 0.22 & 0 & 1 \\
\hline \multicolumn{7}{|c|}{ CEO and Management (M) } \\
\hline CEOTenure & tenure in years & 194 & 2.32 & 2.74 & 0 & 11 \\
\hline CEO Age & age in years & 194 & 45.0 & 7.79 & 29 & 63 \\
\hline CEO Economist & 1 if a CEO has economic education and 0 otherwise & 194 & 0.57 & 0.50 & 0 & 1 \\
\hline CEO Lawyer & 1 if a CEO has legal education and 0 otherwise & 194 & 0.11 & 0.31 & 0 & 1 \\
\hline CEO Insider & 1 if the CEO is former employer of the company and 0 otherwise & 194 & 0.61 & 0.49 & 0 & 1 \\
\hline MSize & number of managers & 194 & 2.96 & 0.50 & 1 & 5 \\
\hline MTenure & average tenure of Ms in years & 194 & 2.45 & 1.99 & 0 & 10 \\
\hline MAge & average age of $\mathrm{Ms}$ in years & 194 & 41.7 & 4.55 & 34 & 55 \\
\hline Mlnsiders & $\%$ of Ms that are former employer of the company & 194 & 0.70 & 0.36 & 0 & 1 \\
\hline MWoman & $\%$ of Ms who are woman & 194 & 0.14 & 0.27 & 0 & 1 \\
\hline MEconomist & $\%$ of Ms who have economic education & 194 & 0.60 & 0.26 & 0 & 1 \\
\hline MLawyers & $\%$ of Ms who have legal education & 194 & 0.12 & 0.20 & 0 & 1 \\
\hline
\end{tabular}

Other corporate governance variables

Government 1 if governments own $50 \%$ or more of equity and 0 otherwise

$\begin{array}{lllll}215 & 0.16 & 0.37 & 0 & 1\end{array}$


Table 1. (continued)

\begin{tabular}{|c|c|c|c|c|c|c|}
\hline Variables & Description & Obs. & Mean & Std. & Min & Max \\
\hline \multicolumn{7}{|c|}{ Other corporate governance variables } \\
\hline Domestic & 1 if domestic shareholder owns $50 \%$ or more of equity and 0 otherwise & 215 & 0.13 & 0.33 & 0 & 1 \\
\hline Foreign & 1 if foreign shareholder owns $50 \%$ or more of equity and 0 otherwise & 215 & 0.78 & 0.41 & 0 & 1 \\
\hline Shareholders & number of shareholders & 194 & 1.67 & 1.09 & 1 & 7 \\
\hline CG inv & 1 if investment corporate government policy present and 0 otherwise & 204 & 0.13 & 0.34 & 0 & 1 \\
\hline GM no & number of all GM attended by fund to firms in their portfolio & 85 & 0.27 & 0.43 & 0 & 1.49 \\
\hline GM co & number of companies GM attended by fund to firms in their portfolio & 85 & 0.17 & 0.26 & 0 & 0.85 \\
\hline Audit & 1 if auditor is changed and 0 otherwise & 194 & 0.09 & 0.28 & 0 & 1 \\
\hline Ethics & 1 if ethic code for senior management present and 0 otherwise & 194 & 0.05 & 0.21 & 0 & 1 \\
\hline Fine no & number of fines imposed by FSA & 215 & 2.71 & 4.97 & 0 & 14 \\
\hline Fine value & log value of fines imposed by FSA & 215 & 0.38 & 0.78 & 0 & 4 \\
\hline \multicolumn{7}{|c|}{ Control variables } \\
\hline Acq. Cost & log acquisition costs & 134 & 15.9 & 1.7 & 10.0 & 18.4 \\
\hline Market Cost & log marketing costs & 134 & 13.4 & 1.6 & 8.9 & 16.2 \\
\hline Salary & log salary cost & 133 & 15.5 & 0.6 & 14.1 & 17.4 \\
\hline Assets & $\log$ OPF net asset value & 194 & 21.0 & 2.1 & 14.3 & 24.6 \\
\hline Equity & $\%$ of equity in investment portfolio & 152 & 0.30 & 0.05 & 0.12 & 0.39 \\
\hline Members & log number of pension members & 215 & 11.8 & 4.0 & 0 & 14.9 \\
\hline$M \& A$ & 1 it the fund acquired or merged with another pension fund & 215 & 0.02 & 0.15 & 0 & 1 \\
\hline
\end{tabular}

\subsection{Methodology}

In the study, a panel model is employed to study the impact of corporate governance on the profitability of a pension fund. Methodologically, the paper uses two econometric techniques: (1) pooled OLS and (2) fixed effects to estimate the impact of corporate governance factors on the performance of pension funds measured by pension unit return, Sharp ratio, ROA, and ROE. In the OLS specification, firm-year fixed effects are included to control for unobserved country characteristics that are allowed to vary over time. The fixed-effects estimation includes time-fixed effects and is employed as a consistency check on the OLS findings. Both models are estimated using robust standard errors.

The Tobit regression model is used to study the relation of dividend payout ratios to the corporate governance factors. This empirical methodology is applied when the dependent variable is truncated at zero and has numerous individual observations displaying such a value in the sample.
One of the primary concerns in the literature is the potential endogeneity between governance measures and performance. Although not reported, I address the potential problem in performing the following test. ${ }^{5}$ Because the prior internal governance may affect pension funds' current performance, I regress performance measures on lags of governance variables, employing OLS and a fixed-effects model. The coefficients of the lag governance factors are generally statistically weaker, but the results are robust.

\section{Results}

In this section, I examine the hypotheses relating external, internal, and other governance mechanisms to pension fund performance. Based on these results, three corporate governance (CG) indices are constructed, employing those factors that were previously found to have a positive influence according to the performance measures. Finally, using partial composition analysis, those three indices are combined in order to test if they may complement each other. 


\subsection{External governance}

In Table 2, the results are presented where the link between past performance of pension funds and the flow of new members is tested. The flow of new members is measured by growth rates in respective years. In the columns $1-4$, the dependent variable is regressed on the pension unit return achieved by the fund over one, two, and three years, respectively. In the following column, cumulative returns are used over the same period. The table reports results for a fixed-effects model. The OLS regression provided similar results, but was not reported for the sake of brevity.

The results confirm that there is no relationship between past performance and the flow of new members. Although short-term return and cumulated returns achieved by a fund are positively related to the flow of new members, the coefficients are insignificant in all of the regressions. This result confirms that members do not select their pension funds using past performance and that they are not responsive to it. On the other hand, the results also suggest that the level of acquisition costs plays a significant role in explaining the number of pension members. Potential members are rather attracted by the funds' representatives, which can be attributed to lack of professional knowledge.

The results are in line with Kominek (2006), who also showed that changes in net asset volume or number of members are not influenced by the monthly cumulated returns over a period of three to 24 months. Hence, the results confirm that pension funds differ from mutual funds, in which investors withdraw capital from poor performers and allocate it to better performing peers (Sirri \& Tufano, 1998). As a fund's performance depends on the amount under management, managers have a strong incentive to outperform their peers. Because such explicit pressure does not exist in the pension funds industry, the internal governance mechanism needs to substitute it.

Table 2. Pension fund performance and changes in members

\begin{tabular}{|c|c|c|c|c|c|c|c|}
\hline \multirow[b]{2}{*}{1 year } & \multicolumn{4}{|c|}{ One year return over the past: } & \multicolumn{3}{|c|}{ Cumulative returns over the past: } \\
\hline & 2.173 & 1.837 & 1.587 & 0.328 & 0.049 & & \\
\hline & $(1.381)$ & $(1.149)$ & (1.438) & $(0.224)$ & $(0.288)$ & & \\
\hline \multirow[t]{2}{*}{2 years } & & -1.291 & -0.964 & 0.438 & & 0.146 & \\
\hline & & $(0.883)$ & $(1.239)$ & $(0.397)$ & & $(0.158)$ & \\
\hline \multirow[t]{2}{*}{3 years } & & & 0.708 & 0.582 & & & 0.327 \\
\hline & & & $(0.538)$ & $(0.334)$ & & & $(0.202)$ \\
\hline \multirow[t]{2}{*}{ Acq. Costs } & & & & $0.043^{*}$ & $0.042^{*}$ & $0.045^{*}$ & $0.045^{*}$ \\
\hline & & & & $(0.024)$ & $(0.023)$ & $(0.022)$ & $(0.022)$ \\
\hline \multirow[t]{2}{*}{ Mark. Costs } & & & & 0.013 & 0.014 & 0.013 & 0.013 \\
\hline & & & & $(0.010)$ & $(0.009)$ & $(0.009)$ & $(0.010)$ \\
\hline \multirow[t]{2}{*}{ Salary } & & & & 0.022 & 0.022 & 0.024 & 0.023 \\
\hline & & & & $(0.031)$ & $(0.030)$ & $(0.028)$ & $(0.029)$ \\
\hline \multirow[t]{2}{*}{$M \& A$} & $1.302^{* *}$ & $1.315^{* *}$ & $1.333^{* *}$ & $1.084^{* * *}$ & $1.085^{* * *}$ & $1.078^{* * *}$ & $1.077^{* * *}$ \\
\hline & (0.509) & $(0.507)$ & $(0.523)$ & $(0.021)$ & $(0.017)$ & $(0.020)$ & (0.019) \\
\hline Obs & 173 & 173 & 152 & 117 & 117 & 117 & 117 \\
\hline Firms & 21 & 21 & 17 & 16 & 16 & 16 & 16 \\
\hline$R^{2}$ & 0.54 & 0.55 & 0.57 & 0.88 & 0.88 & 0.88 & 0.88 \\
\hline
\end{tabular}

Note: All regressions are run using fixed-effects model including year dummies. Variables definitions are in Table 1. Robust standard errors are reported in parentheses. ${ }^{* *},{ }^{* *}$ and ${ }^{*}$ indicate significance at 1,5 , and 10 percent levels, respectively. 


\subsection{Internal governance}

\subsubsection{Board structure and characteristics}

Table 3 reports the results from regressing fund performance measures on the primary board structure characteristics. I find a significant negative relationship of the board size with all of the fund profitability measures. However, the coefficient is only significant for DOA (DOE) and for ROA (ROE) in the OLS regression. A negative impact of large boards on profitability also suggests the coefficient M/B size: it is negative and significantly related to ROA (ROE), which may confirm that increased monitoring by board members is outweighed by the poorer communication and decision making of the management (Jensen, 1993). However, both coefficients are insignificant for the pension unit's return and the Sharp ratio.

The results also document only weak evidence that having a large proportion of outsiders is positively related to the Sharp ratio, while other board charac- teristics are insignificantly related to it and the pension unit's return. I find, however, that having a large number of foreigners on the board is significantly and negatively related to ROE as well as the dividend ratios. These results are in line with Masulis et al. (2010), who found that in the US foreign directors are associated with a significantly poorer performance of the firms. Moreover, I find that having older board members has a negative and significant impact on the dividend policy. The presence of former managers on the board has a significant opposite effect.

The work of the board is heavily influenced by the Chairman. In a two-tier board, the Chairman is responsible for organizing the board meetings and setting the agenda. Moreover, the Chairman is in contact with the management, who provide him with information on topics that require the attention of the board. Consequently, the Chairman influences the work and efficiency of the board in monitoring the management.

Table 3. Board structure and pension fund performance

\begin{tabular}{|c|c|c|c|c|c|c|c|c|c|c|}
\hline & \multicolumn{4}{|l|}{ OLS } & \multicolumn{4}{|c|}{ Fixed-effects } & \multicolumn{2}{|l|}{ Tobit } \\
\hline & Return & Sharp & ROE & $\mathrm{ROA}$ & Return & Sharp & ROE & $\mathrm{ROA}$ & DOE & DOA \\
\hline \multirow[t]{2}{*}{ BSize } & 0.000 & -0.006 & $-0.579^{* *}$ & $-0.171^{* * *}$ & 0.003 & 0.039 & -0.279 & -0.116 & $-0.044^{* *}$ & $-0.034^{*}$ \\
\hline & $(0.002)$ & $(0.045)$ & $(0.243)$ & $(0.054)$ & $(0.002)$ & $(0.036)$ & $(0.169)$ & $(0.083)$ & $(0.022)$ & $(0.019)$ \\
\hline \multirow[t]{2}{*}{ BSize2 } & 0.000 & 0.000 & 0.000 & -0.000 & -0.000 & -0.000 & -0.000 & -0.000 & -0.000 & -0.000 \\
\hline & $(0.000)$ & $(0.000)$ & $(0.000)$ & $(0.000)$ & $(0.000)$ & $(0.000)$ & $(0.000)$ & $(0.000)$ & $(0.000)$ & $(0.000)$ \\
\hline \multirow[t]{2}{*}{ M/B Size } & 0.001 & -0.207 & $-2.730^{*}$ & $-1.169^{* *}$ & -0.004 & -0.204 & $-3.835^{* * *}$ & $-1.058^{*}$ & -0.217 & -0.150 \\
\hline & $(0.017)$ & $(0.241)$ & $(1.596)$ & $(0.490)$ & $(0.016)$ & $(0.267)$ & $(1.210)$ & $(0.583)$ & $(0.202)$ & $(0.175)$ \\
\hline \multirow[t]{2}{*}{ BOutsiders } & 0.062 & -1.453 & 0.815 & 1.310 & 0.045 & -0.694 & $-4.561^{* *}$ & -0.349 & 0.322 & 0.270 \\
\hline & $(0.055)$ & $(0.893)$ & (7.594) & $(1.749)$ & $(0.044)$ & $(0.664)$ & (1.778) & (1.618) & (1.888) & $(1.604)$ \\
\hline \multirow[t]{2}{*}{ BOutsiders2 } & -0.053 & $1.986^{*}$ & -1.977 & -2.164 & -0.029 & 1.184 & 1.895 & -0.045 & -1.202 & -0.973 \\
\hline & $(0.075)$ & (1.104) & $(7.921)$ & $(2.082)$ & $(0.050)$ & $(0.748)$ & $(2.357)$ & (1.939) & (1.930) & $(1.655)$ \\
\hline \multirow[t]{2}{*}{ BForeigners } & 0.017 & -0.084 & -0.858 & 0.036 & 0.024 & 0.184 & $-1.256^{*}$ & 0.027 & $-0.676^{* * *}$ & $-0.520^{* * *}$ \\
\hline & $(0.015)$ & $(0.218)$ & $(1.058)$ & $(0.306)$ & $(0.015)$ & $(0.331)$ & $(0.727)$ & $(0.634)$ & $(0.154)$ & $(0.137)$ \\
\hline \multirow[t]{2}{*}{ BWoman } & 0.002 & -0.052 & -0.145 & 0.268 & 0.011 & 0.147 & -0.904 & -1.025 & 0.014 & 0.021 \\
\hline & (0.019) & $(0.260)$ & $(1.076)$ & $(0.470)$ & $(0.023)$ & $(0.421)$ & $(1.507)$ & $(0.668)$ & $(0.215)$ & $(0.186)$ \\
\hline \multirow[t]{2}{*}{ BAge } & 0.000 & 0.005 & -0.008 & 0.015 & 0.000 & 0.012 & 0.059 & 0.026 & $-0.015^{* *}$ & $-0.012^{* *}$ \\
\hline & $(0.000)$ & $(0.009)$ & $(0.035)$ & $(0.017)$ & $(0.001)$ & (0.008) & $(0.045)$ & $(0.018)$ & $(0.006)$ & $(0.005)$ \\
\hline \multirow[t]{2}{*}{ BFormer } & -0.000 & 0.078 & 0.385 & 0.091 & 0.006 & 0.022 & -0.141 & -0.235 & $0.110^{* *}$ & $0.096^{* *}$ \\
\hline & $(0.007)$ & (0.078) & $(0.369)$ & $(0.136)$ & $(0.004)$ & $(0.090)$ & $(0.427)$ & $(0.145)$ & $(0.048)$ & $(0.042)$ \\
\hline
\end{tabular}


Table 3. (continued)

\begin{tabular}{|c|c|c|c|c|c|c|c|c|c|c|}
\hline & \multicolumn{4}{|l|}{ OLS } & \multicolumn{4}{|c|}{ Fixed-effects } & \multicolumn{2}{|l|}{ Tobit } \\
\hline & Return & Sharp & ROE & $\mathrm{ROA}$ & Return & Sharp & ROE & $\mathrm{ROA}$ & DOE & DOA \\
\hline \multirow[t]{2}{*}{ Assets } & 0.002 & -0.018 & 1.443 & 0.378 & 0.012 & -0.248 & -0.044 & -0.408 & $0.380^{*}$ & $0.345^{*}$ \\
\hline & $(0.004)$ & $(0.062)$ & (1.208) & $(0.245)$ & $(0.012)$ & $(0.234)$ & $(1.252)$ & (0.309) & $(0.226)$ & (0.197) \\
\hline \multirow[t]{2}{*}{ Members } & & & -1.502 & -0.187 & & & -2.994 & -0.497 & -0.214 & -0.205 \\
\hline & & & (1.606) & (0.319) & & & $(2.115)$ & $(0.330)$ & $(0.270)$ & $(0.235)$ \\
\hline Obs & 194 & 180 & 188 & 188 & 194 & 180 & 188 & 188 & 118 & 118 \\
\hline Firms & 21 & 17 & 21 & 21 & 21 & 17 & 21 & 21 & 16 & 16 \\
\hline$R^{2}$ & 0.89 & 0.90 & 0.14 & 0.49 & 0.90 & 0.92 & 0.16 & 0.48 & & \\
\hline
\end{tabular}

Note: Regressions are run by OLS, and the fixed-effects model, and the Tobit model. Variables definitions are in Table 1. OLS specifications include firm fixed effects and all specifications include year dummies. Robust standard errors are reported in parentheses. ${ }^{* *},{ }^{* *}$ and ${ }^{*}$ indicate significance at 1,5, and 10 percent levels, respectively.

Table 4 presents the regression on the impact of Chairman characteristics on pension fund performance. While the estimated coefficient for the independent chairman is insignificant, his age and educational background are significant. Age is positively correlated with the Sharp ratio and ROE, while the economic education is positively related to the pension unit's return and the Sharp ratio. In contrast, both coefficients are significant and negatively related to the two dividend payout ratios.

Table 4. Board Chairman characteristics and pension fund performance

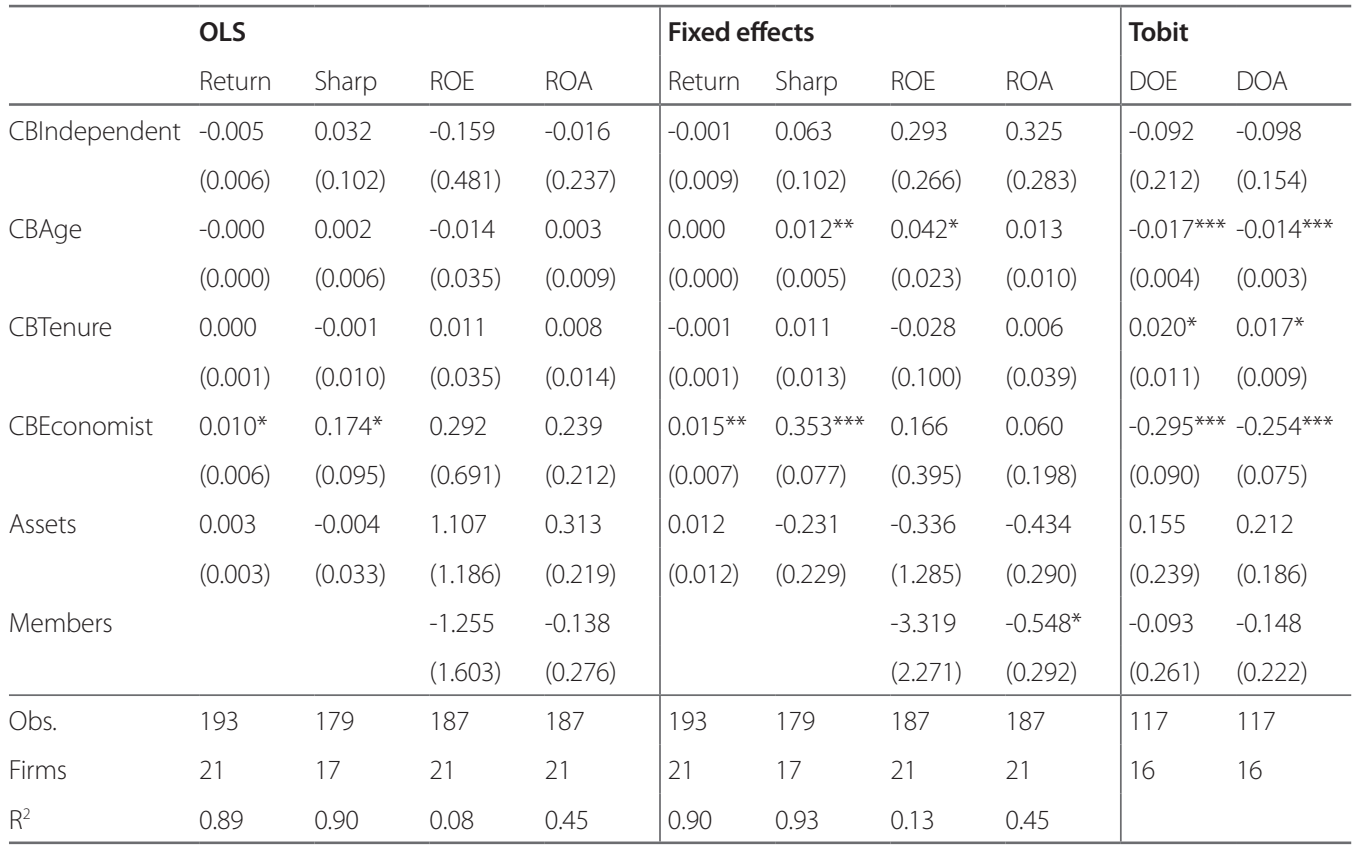

Note: Regressions are run by OLS, and the fixed-effects model, and the Tobit model. Variables definitions are in Table 1. OLS specifications include firm fixed effects and all specifications include year dummies. Robust standard errors are reported in parentheses. ${ }^{* *},{ }^{* *}$ and ${ }^{*}$ indicate significance at 1, 5, and 10 percent levels, respectively. 


\subsubsection{Independent board member characteristics}

The weak statistical and positive relationship between a large number of outsiders and the pension unit return other characteristics may be determined by its characteristics, what presents the results in Table 5 . Controlling for the board characteristics such as age and tenure, the results show that a small number of outsiders have a negative impact on the Sharp ratio. In contrast, I confirm that the large number of outsiders is positively and statistically related to the Sharp ratio. The estimated coefficient for age is positive and significant for ROA but also for the Sharp ratio.

This result is inconsistent with the idea that younger outsiders, who are more likely to be plan partici- pants, are better at monitoring the fund. The statistics in Table 1, however, show that the average age for outsiders is 54.7 years, while only those who were 30 years old or younger in 1999 had to join the DC pension funds. Moreover, I do not have information on the membership of outsiders in pension plans and, therefore, age may be a proxy for experience, which may explain the sign of the age coefficient. The results also show that the long tenure of outsiders is significant and negatively related to ROA, which suggests that they are less effective because they are more likely to befriend managers (Vafeas, 2003).

Table 5. Independent Board Members structure and pension fund performance

\begin{tabular}{|c|c|c|c|c|c|c|c|c|c|c|}
\hline & \multicolumn{4}{|l|}{ OLS } & \multicolumn{4}{|c|}{ Fixed effects } & \multicolumn{2}{|l|}{ Tobit } \\
\hline & Return & Sharp & ROE & $\mathrm{ROA}$ & Return & Sharp & $\mathrm{ROE}$ & $\mathrm{ROA}$ & DOE & DOA \\
\hline \multirow[t]{2}{*}{ BSize } & -0.001 & -0.004 & $-0.404^{*}$ & $-0.078^{*}$ & 0.003 & 0.047 & -0.115 & -0.056 & -0.014 & -0.011 \\
\hline & $(0.002)$ & $(0.043)$ & $(0.208)$ & $(0.045)$ & $(0.002)$ & $(0.040)$ & $(0.178)$ & $(0.083)$ & $(0.025)$ & $(0.021)$ \\
\hline \multirow[t]{2}{*}{ BSize2 } & -0.000 & 0.000 & 0.000 & -0.000 & -0.000 & -0.000 & -0.001 & -0.000 & 0.000 & 0.000 \\
\hline & $(0.000)$ & $(0.000)$ & $(0.000)$ & $(0.000)$ & $(0.000)$ & $(0.000)$ & $(0.000)$ & $(0.000)$ & $(0.000)$ & $(0.000)$ \\
\hline \multirow[t]{2}{*}{ BOutsiders } & -0.030 & $-3.221^{* * *}$ & -0.617 & 0.076 & -0.015 & $-2.604^{* * *}$ & -5.998 & -1.520 & 0.068 & -0.056 \\
\hline & $(0.074)$ & $(1.214)$ & (8.678) & $(2.496)$ & $(0.059)$ & $(0.638)$ & (3.638) & $(1.706)$ & (1.819) & (1.627) \\
\hline \multirow[t]{2}{*}{ BOutsiders2 } & 0.028 & $3.712^{* * *}$ & -0.054 & -0.658 & 0.029 & $3.072^{* * *}$ & 4.032 & 1.003 & -0.462 & -0.250 \\
\hline & $(0.083)$ & $(1.381)$ & (8.876) & $(2.678)$ & $(0.057)$ & $(0.718)$ & (3.562) & (1.936) & (1.909) & (1.707) \\
\hline \multirow[t]{2}{*}{ BlAge } & $0.001^{*}$ & $0.010^{* *}$ & 0.013 & $0.013^{*}$ & 0.000 & $0.011^{* * *}$ & 0.025 & $0.020^{* * *}$ & -0.001 & -0.000 \\
\hline & $(0.000)$ & $(0.004)$ & $(0.021)$ & $(0.007)$ & $(0.000)$ & $(0.004)$ & $(0.020)$ & $(0.005)$ & $(0.004)$ & $(0.003)$ \\
\hline \multirow[t]{2}{*}{ BI Tenure max } & -0.001 & 0.001 & 0.051 & -0.020 & -0.001 & -0.008 & -0.103 & $-0.074^{* *}$ & 0.008 & 0.005 \\
\hline & $(0.001)$ & $(0.012)$ & $(0.084)$ & $(0.017)$ & $(0.001)$ & $(0.015)$ & $(0.091)$ & $(0.031)$ & $(0.013)$ & $(0.011)$ \\
\hline \multirow[t]{2}{*}{ Assets } & 0.003 & -0.005 & 1.239 & 0.313 & 0.012 & -0.255 & -0.301 & -0.402 & 0.166 & 0.174 \\
\hline & $(0.003)$ & $(0.045)$ & (1.205) & $(0.211)$ & $(0.012)$ & $(0.224)$ & $(1.295)$ & $(0.308)$ & $(0.240)$ & $(0.204)$ \\
\hline \multirow[t]{2}{*}{ Members } & & & -1.240 & -0.081 & & & -3.517 & $-0.696^{*}$ & 0.011 & -0.024 \\
\hline & & & $(1.545)$ & $(0.285)$ & & & $(2.163)$ & $(0.353)$ & $(0.302)$ & $(0.257)$ \\
\hline Obs. & 189 & 175 & 184 & 184 & 189 & 175 & 184 & 184 & 117 & 117 \\
\hline Firms & 21 & 17 & 21 & 21 & 21 & 17 & 21 & 21 & 16 & 16 \\
\hline $\mathrm{R}^{2}$ & 0.89 & 0.90 & 0.11 & 0.48 & 0.90 & 0.92 & 0.13 & 0.46 & & \\
\hline
\end{tabular}

Note: Regressions are run by OLS, and the fixed-effects model, and the Tobit model. Variables definitions are in Table 1. OLS specifications include firm fixed effects and all specifications include year dummies. Robust standard errors are reported in parentheses. ${ }^{* * *},{ }^{* *}$ and ${ }^{*}$ indicate significance at 1,5 , and 10 percent levels, respectively. 
A further analysis of the outsiders' characteristics reveals that their educational background may also be important. The results in Table 6 show that having a large number of outsiders with education in economics does not improve the pension unit return. Moreover, the coefficient is significant and negatively related to ROE. I find also that the coefficient showing the ra- tio of outsiders with legal education is also negatively related to ROE and to the Sharp ratio. In contrast, it is positively correlated with ROA and to both dividend payout ratios. Consequently, the results show only a weak justification for the regulation requiring that at least half of the members need to have either a legal or an economics education.

Table 6. Independent Board Member education and pension fund performance

\begin{tabular}{|c|c|c|c|c|c|c|c|c|c|c|}
\hline & \multicolumn{4}{|l|}{ OLS } & \multicolumn{4}{|c|}{ Fixed effects } & \multicolumn{2}{|l|}{ Tobit } \\
\hline & Return & Sharp & ROE & $\mathrm{ROA}$ & Return & Sharp & ROE & $\mathrm{ROA}$ & DOE & DOA \\
\hline \multirow[t]{2}{*}{ BSize } & -0.001 & -0.008 & $-0.423^{* *}$ & -0.075 & 0.003 & 0.041 & -0.167 & -0.036 & -0.022 & -0.018 \\
\hline & $(0.002)$ & $(0.045)$ & $(0.212)$ & $(0.046)$ & $(0.002)$ & $(0.037)$ & $(0.171)$ & $(0.078)$ & $(0.027)$ & $(0.023)$ \\
\hline \multirow[t]{2}{*}{ BSize2 } & -0.000 & -0.000 & 0.000 & -0.000 & -0.000 & -0.000 & -0.000 & $-0.001^{* *}$ & -0.000 & -0.000 \\
\hline & $(0.000)$ & $(0.000)$ & $(0.000)$ & $(0.000)$ & $(0.000)$ & $(0.000)$ & $(0.000)$ & $(0.000)$ & $(0.000)$ & $(0.000)$ \\
\hline \multirow[t]{2}{*}{ BOutsiders } & 0.006 & $-2.195^{*}$ & 7.464 & 0.096 & 0.009 & $-2.375^{* *}$ & -1.383 & $-5.165^{* *}$ & -0.763 & -0.620 \\
\hline & $(0.088)$ & (1.199) & $(11.724)$ & $(2.327)$ & $(0.060)$ & $(0.868)$ & (3.936) & $(2.268)$ & (2.396) & (1.968) \\
\hline \multirow[t]{2}{*}{ BOutsiders2 } & -0.013 & $2.512^{*}$ & -9.591 & -0.674 & 0.002 & $2.865^{* *}$ & -1.087 & $5.248^{*}$ & 0.669 & 0.560 \\
\hline & $(0.096)$ & (1.383) & $(12.550)$ & (2.568) & (0.067) & $(1.005)$ & $(4.671)$ & $(2.550)$ & $(2.478)$ & (2.045) \\
\hline \multirow[t]{2}{*}{ BlAge } & $0.001^{*}$ & $0.010^{* *}$ & 0.015 & $0.014^{*}$ & 0.000 & $0.016^{*}$ & 0.036 & $0.027^{* * *}$ & 0.007 & 0.006 \\
\hline & $(0.000)$ & $(0.005)$ & $(0.021)$ & $(0.008)$ & $(0.000)$ & $(0.008)$ & $(0.021)$ & $(0.008)$ & $(0.005)$ & $(0.004)$ \\
\hline \multirow[t]{2}{*}{ BITenure max } & -0.001 & -0.008 & -0.024 & -0.025 & -0.001 & -0.010 & -0.093 & $-0.088^{* * *}$ & 0.007 & 0.004 \\
\hline & $(0.001)$ & $(0.015)$ & $(0.102)$ & $(0.022)$ & $(0.001)$ & $(0.014)$ & $(0.080)$ & $(0.021)$ & $(0.013)$ & $(0.011)$ \\
\hline \multirow[t]{2}{*}{ BIEconomy } & -0.016 & -0.269 & -2.251 & -0.091 & -0.012 & -0.350 & $-1.904^{* *}$ & 0.576 & 0.287 & 0.236 \\
\hline & $(0.014)$ & $(0.165)$ & $(1.950)$ & $(0.288)$ & $(0.022)$ & $(0.370)$ & $(0.853)$ & $(0.580)$ & $(0.362)$ & $(0.303)$ \\
\hline \multirow[t]{2}{*}{ BILaw } & -0.016 & $-0.370^{* *}$ & -3.206 & -0.028 & -0.012 & -0.215 & $-2.139^{* *}$ & $1.305^{*}$ & $0.641^{*}$ & $0.529^{*}$ \\
\hline & $(0.017)$ & $(0.186)$ & $(2.397)$ & $(0.345)$ & $(0.018)$ & $(0.285)$ & $(0.763)$ & $(0.688)$ & $(0.371)$ & $(0.311)$ \\
\hline \multirow[t]{2}{*}{ Assets } & 0.004 & 0.030 & 1.402 & 0.323 & 0.013 & -0.249 & -0.158 & $-0.566^{*}$ & 0.083 & 0.132 \\
\hline & $(0.004)$ & $(0.050)$ & (1.134) & $(0.221)$ & $(0.012)$ & $(0.236)$ & $(1.253)$ & $(0.286)$ & $(0.273)$ & $(0.229)$ \\
\hline \multirow[t]{2}{*}{ Members } & & & -1.158 & -0.092 & & & -3.366 & $-0.712^{* *}$ & 0.101 & 0.019 \\
\hline & & & (1.524) & $(0.293)$ & & & $(2.278)$ & $(0.328)$ & $(0.341)$ & $(0.287)$ \\
\hline Obs. & 189 & 175 & 184 & 184 & 189 & 175 & 184 & 184 & 117 & 117 \\
\hline Firms & 21 & 17 & 21 & 21 & 21 & 17 & 21 & 21 & 16 & 16 \\
\hline$R^{2}$ & 0.89 & 0.90 & 0.16 & 0.48 & 0.90 & 0.93 & 0.13 & 0.49 & & \\
\hline
\end{tabular}

Note: Regressions are run by OLS, and the fixed-effects model, and the Tobit model. Variables definitions are in Table 1. OLS specifications include firm fixed effects and all specifications include year dummies. Robust standard errors are reported in parentheses. ${ }^{* *},{ }^{* *}$ and ${ }^{*}$ indicate significance at 1,5 , and 10 percent levels, respectively. 

Table 7. (continued)

\begin{tabular}{|c|c|c|c|c|c|c|c|c|c|c|}
\hline & OLS & & & & $\mathrm{FE}$ & & & & Tobit & \\
\hline & Return & Sharp & ROE & $\mathrm{ROA}$ & Return & Sharp & ROE & $\mathrm{ROA}$ & DOE & DOA \\
\hline & $(0.005)$ & $(0.046)$ & $(1.431)$ & $(0.247)$ & $(0.011)$ & $(0.181)$ & (1.373) & $(0.307)$ & $(0.232)$ & $(0.143)$ \\
\hline \multirow[t]{2}{*}{ Members } & & & -1.277 & -0.076 & & & -3.044 & $-0.645^{* *}$ & -0.105 & -0.090 \\
\hline & & & (1.799) & $(0.340)$ & & & $(2.354)$ & $(0.307)$ & $(0.299)$ & $(0.174)$ \\
\hline Obs. & 189 & 175 & 184 & 184 & 189 & 175 & 184 & 184 & 117 & 117 \\
\hline Firms & 21 & 17 & 21 & 21 & 21 & 17 & 21 & 21 & 16 & 16 \\
\hline$R^{2}$ & 0.89 & 0.91 & 0.15 & 0.50 & 0.91 & 0.93 & 0.16 & 0.50 & & \\
\hline
\end{tabular}

Note: Regressions are run by OLS, and the fixed-effects model, and the Tobit model. Variables definitions are in Table 1. OLS specifications include firm fixed effects and all specifications include year dummies. Robust standard errors are reported in parentheses. ${ }^{* *},{ }^{* *}$ and ${ }^{*}$ indicate significance at 1,5, and 10 percent levels, respectively.

Lastly, the results in Table 8 show that other attributes of independent board members may be important in explaining the performance of the pension funds. The estimations suggest that funds that feature outsiders with political connections are underperforming, as the coefficient is significant and negative in almost all of the specifications. The results do not show any significant impact on performance, however, if the outside board members are either interlocked or if they have been involved in a criminal investigation in the past.

Table 8. Independent Board Member other characteristics and pension fund performance

\begin{tabular}{|c|c|c|c|c|c|c|c|c|c|c|}
\hline & \multicolumn{4}{|l|}{ OLS } & \multicolumn{4}{|c|}{ Fixed effects } & \multicolumn{2}{|l|}{ Tobit } \\
\hline & Return & Sharp & ROE & $\mathrm{ROA}$ & Return & Sharp & $\mathrm{ROE}$ & $\mathrm{ROA}$ & DOE & DOA \\
\hline \multirow[t]{2}{*}{ BSize } & -0.001 & -0.009 & $-0.414^{*}$ & -0.061 & 0.003 & 0.043 & -0.132 & -0.034 & 0.010 & 0.009 \\
\hline & $(0.002)$ & $(0.053)$ & $(0.228)$ & $(0.056)$ & $(0.002)$ & $(0.049)$ & $(0.186)$ & $(0.085)$ & (0.027) & $(0.023)$ \\
\hline \multirow[t]{2}{*}{ BSize2 } & -0.000 & 0.000 & 0.000 & -0.000 & -0.000 & -0.000 & -0.000 & -0.001 & -0.000 & -0.000 \\
\hline & $(0.000)$ & $(0.000)$ & $(0.000)$ & $(0.000)$ & $(0.000)$ & $(0.000)$ & $(0.001)$ & $(0.000)$ & (0.000) & $(0.000)$ \\
\hline \multirow[t]{2}{*}{ BOutsiders } & -0.029 & $-3.344^{* * *}$ & -1.246 & -0.132 & -0.020 & $-2.564^{* *}$ & -5.553 & -1.870 & -1.166 & -1.021 \\
\hline & $(0.076)$ & $(1.263)$ & $(8.811)$ & $(2.522)$ & $(0.069)$ & $(0.921)$ & (3.464) & $(1.773)$ & $(2.022)$ & $(1.884)$ \\
\hline \multirow[t]{2}{*}{ BOutsiders2 } & 0.024 & $3.793^{* * *}$ & 0.693 & 0.015 & 0.038 & $2.942^{* *}$ & 3.364 & 2.111 & 1.408 & 1.238 \\
\hline & $(0.085)$ & $(1.424)$ & (8.825) & $(2.737)$ & $(0.079)$ & $(1.166)$ & (3.512) & $(2.152)$ & (2.114) & (1.962) \\
\hline \multirow[t]{2}{*}{ BIAge } & 0.001 & $0.011^{* *}$ & 0.016 & $0.013^{*}$ & 0.000 & $0.011^{* *}$ & 0.022 & $0.018^{* *}$ & -0.002 & -0.001 \\
\hline & $(0.000)$ & $(0.005)$ & $(0.021)$ & $(0.007)$ & $(0.000)$ & $(0.004)$ & $(0.021)$ & $(0.006)$ & $(0.004)$ & $(0.003)$ \\
\hline \multirow[t]{2}{*}{ BITenure max } & -0.001 & 0.000 & 0.051 & -0.014 & -0.001 & -0.008 & -0.105 & $-0.066^{* *}$ & 0.014 & 0.010 \\
\hline & $(0.001)$ & $(0.010)$ & $(0.079)$ & $(0.016)$ & $(0.001)$ & $(0.014)$ & $(0.090)$ & $(0.029)$ & $(0.013)$ & $(0.011)$ \\
\hline \multirow[t]{2}{*}{ BIPolitical } & 0.002 & -0.003 & -0.248 & $-0.353^{* * *}$ & -0.002 & 0.015 & -0.007 & $-0.322^{*}$ & $-0.197^{* * *}$ & $-0.162^{* * *}$ \\
\hline & $(0.005)$ & $(0.081)$ & $(0.286)$ & (0.128) & (0.006) & $(0.112)$ & (0.439) & $(0.156)$ & (0.069) & (0.058) \\
\hline \multirow[t]{2}{*}{ Bllnterlocked } & -0.000 & 0.028 & 0.218 & 0.197 & -0.001 & 0.033 & 0.318 & 0.095 & -0.063 & -0.038 \\
\hline & $(0.005)$ & $(0.101)$ & $(0.314)$ & $(0.168)$ & (0.010) & $(0.174)$ & (0.439) & $(0.196)$ & (0.144) & (0.120) \\
\hline \multirow[t]{2}{*}{ BICriminal } & -0.003 & 0.084 & 0.672 & 0.220 & 0.000 & 0.060 & -0.023 & -0.237 & -0.176 & -0.149 \\
\hline & $(0.008)$ & (0.095) & $(0.452)$ & (0.189) & $(0.006)$ & $(0.147)$ & $(0.547)$ & $(0.180)$ & (0.166) & $(0.142)$ \\
\hline
\end{tabular}


Table 8. (continued)

\begin{tabular}{|c|c|c|c|c|c|c|c|c|c|c|}
\hline & \multicolumn{4}{|l|}{ OLS } & \multicolumn{4}{|c|}{ Fixed effects } & \multicolumn{2}{|l|}{ Tobit } \\
\hline & Return & Sharp & ROE & $\mathrm{ROA}$ & Return & Sharp & ROE & $\mathrm{ROA}$ & DOE & DOA \\
\hline \multirow[t]{2}{*}{ Assets } & 0.003 & -0.006 & 1.193 & 0.235 & 0.012 & -0.248 & -0.235 & -0.461 & 0.118 & 0.154 \\
\hline & $(0.004)$ & $(0.059)$ & $(1.241)$ & $(0.210)$ & $(0.012)$ & $(0.205)$ & (1.418) & $(0.337)$ & $(0.256)$ & $(0.222)$ \\
\hline \multirow[t]{2}{*}{ Members } & & & -1.239 & -0.035 & & & -3.542 & -0.543 & 0.078 & 0.010 \\
\hline & & & (1.579) & $(0.283)$ & & & (2.344) & $(0.410)$ & $(0.317)$ & (0.273) \\
\hline Obs. & 189 & 175 & 184 & 184 & 189 & 175 & 184 & 184 & 117 & 117 \\
\hline Firms & 21 & 17 & 21 & 21 & 21 & 17 & 21 & 21 & 16 & 16 \\
\hline$R^{2}$ & 0.89 & 0.90 & 0.12 & 0.50 & 0.90 & 0.93 & 0.13 & 0.48 & & \\
\hline
\end{tabular}

Note: Regressions are run by OLS, and the fixed-effects model, and the Tobit model. Variables definitions are in Table 1. OLS specifications include firm fixed effects and all specifications include year dummies. Robust standard errors are reported in parentheses. ${ }^{* *},{ }^{* *}$ and ${ }^{*}$ indicate significance at 1,5 , and 10 percent levels, respectively.

\subsubsection{Management and board turnover}

A way to analyze the efficiency of the existing internal governance in pension funds is to look at the management and board turnover. It can be expected that if the internal mechanism is working properly then the probability of a significant managerial or board turnover is inversely related to the investment or economic performance of the pension fund.

A logit model is employed to analyze whether the supervisory board or general assembly discipline the managers or board members, respectively, when the funds perform badly. In the model, the dependent variable shows changes to either in the management or the supervisory board. As explanatory variables, single period lagged pension fund performance variables are used because disciplinary actions may only take place after poor firm performance. In the regression some variables are also included to control for managers, board members, and ownership characteristics of the pension fund. The results presented in Tables 9-12 show the marginal effects of the logit model for changes to the CEO, management, Chairman and supervisory board, respectively.

The results in Table 9 show that changes in the CEO are not directly related to the performance of the pension funds. The coefficients for pension fund performance, however, have all negative signs with the exception of the dividend policy. One explanation for the weak results is that the depended variable includes the forced and voluntary turnover. Furthermore, Jenter and Lewellen (2010) showed that the probability of performance induced dismissal increases with time. This increase means that those performance-induced dismissals are still likely, but when the pension fund underperforms over a longer period. In the pension industry, an additional explanation could be that the investment results are attributed to a former manager for a longer time because it takes a longer time to change the portfolio, which is also often costly. Hence, the decision to change a CEO or manager may be delayed over a longer time period. Additionally, as the industry is strongly regulated it may also take some time to find a candidate suitable for the job, which may explain why the coefficient for CEO tenure is significant and negative.

The results for the management turnover presented in Table 10 are in line with the results for the CEO. The coefficients for the lagged pension performance variables are negative but again insignificant. Again, the regression shows that management turnover is negatively and significantly related to their tenure. The results also show that changes in the management are less likely when the management board is already small, which may confirm that regulations can be an important factor in understanding the turnover in pension funds. On the other hand, I also find that the managers who are former employees of the company are less likely to be dismissed. One explanation is that their past reputations prevent the board members from dismissing them, even when the fund is underperforming. Another and more likely explanation is that board members may be less willing to replace managers who were delegated by the owner to manage the fund. Consequently, those results may suggest problems in the internal governance mechanism of the pension funds. 
Table 9. CEO turnover and past pension fund performance

\begin{tabular}{|c|c|c|c|c|c|c|}
\hline & (1) & (2) & (3) & (4) & (5) & (6) \\
\hline \multirow[t]{2}{*}{ BOutsiders } & -0.182 & -0.107 & -0.276 & -0.203 & -0.092 & -0.091 \\
\hline & $(0.341)$ & $(0.340)$ & $(0.403)$ & $(0.349)$ & $(0.267)$ & $(0.267)$ \\
\hline \multirow[t]{2}{*}{ BOutsiders2 } & 0.272 & 0.207 & 0.333 & 0.268 & 0.111 & 0.111 \\
\hline & $(0.495)$ & $(0.509)$ & $(0.525)$ & $(0.480)$ & $(0.380)$ & $(0.380)$ \\
\hline \multirow[t]{2}{*}{ CEOTenure } & $-0.055^{* * *}$ & $-0.057^{* * *}$ & $-0.057^{* * *}$ & $-0.056^{* * *}$ & $-0.057^{* * *}$ & $-0.057^{* * *}$ \\
\hline & $(0.017)$ & $(0.016)$ & $(0.018)$ & $(0.017)$ & (0.019) & (0.019) \\
\hline \multirow[t]{2}{*}{ CEOAge } & 0.001 & 0.003 & 0.002 & 0.002 & 0.001 & 0.001 \\
\hline & $(0.002)$ & $(0.003)$ & $(0.002)$ & $(0.002)$ & $(0.002)$ & $(0.002)$ \\
\hline \multirow[t]{2}{*}{ CEOEconomist } & -0.003 & -0.021 & -0.009 & -0.009 & 0.003 & 0.003 \\
\hline & $(0.031)$ & $(0.040)$ & $(0.033)$ & $(0.034)$ & $(0.027)$ & $(0.027)$ \\
\hline \multirow[t]{2}{*}{ CEOLawyer } & -0.027 & -0.033 & -0.027 & -0.040 & -0.025 & -0.025 \\
\hline & $(0.048)$ & $(0.050)$ & $(0.049)$ & $(0.051)$ & $(0.055)$ & $(0.055)$ \\
\hline \multirow[t]{2}{*}{ CEOInsider } & 0.018 & -0.002 & -0.003 & -0.003 & 0.018 & 0.018 \\
\hline & $(0.051)$ & $(0.043)$ & $(0.042)$ & $(0.044)$ & $(0.057)$ & $(0.057)$ \\
\hline \multirow[t]{2}{*}{ Lag Return } & -0.498 & & & & & \\
\hline & $(0.759)$ & & & & & \\
\hline \multirow[t]{2}{*}{ Lag Sharp } & & -0.075 & & & & \\
\hline & & $(0.081)$ & & & & \\
\hline \multirow[t]{2}{*}{ Lag ROE } & & & -0.003 & & & \\
\hline & & & $(0.006)$ & & & \\
\hline \multirow[t]{2}{*}{ Lag ROA } & & & & -0.025 & & \\
\hline & & & & $(0.025)$ & & \\
\hline \multirow[t]{2}{*}{ DOE } & & & & & 0.089 & \\
\hline & & & & & $(0.111)$ & \\
\hline \multirow[t]{2}{*}{ DOA } & & & & & & 0.103 \\
\hline & & & & & & $(0.128)$ \\
\hline Obs & 173 & 163 & 168 & 168 & 188 & 188 \\
\hline
\end{tabular}

Note: Estimation presents the marginal effects at means of the independent variable after the regressions are run by Logit model. All specifications include year dummies. Variables definitions are in Table 1. Robust standard errors are reported in parentheses. ${ }^{* *},{ }^{* *}$ and ${ }^{*}$ indicate significance at 1,5 , and 10 percent levels, respectively. 
Table 10. Management turnover on past pension fund performance

\begin{tabular}{|c|c|c|c|c|c|c|}
\hline & (1) & $(2)$ & (3) & (4) & (5) & (6) \\
\hline \multirow[t]{2}{*}{ BOutsiders } & -0.087 & -0.082 & -0.395 & -0.234 & 0.058 & 0.061 \\
\hline & $(0.837)$ & $(0.881)$ & (0.892) & $(0.866)$ & $(0.731)$ & $(0.729)$ \\
\hline \multirow[t]{2}{*}{ BOutsiders2 } & -0.464 & -0.485 & -0.111 & -0.256 & -0.690 & -0.692 \\
\hline & $(1.085)$ & $(1.147)$ & $(1.146)$ & (1.143) & (0.968) & (0.968) \\
\hline \multirow[t]{2}{*}{ Mage } & -0.009 & 0.003 & -0.007 & -0.009 & -0.007 & -0.007 \\
\hline & $(0.013)$ & $(0.015)$ & $(0.013)$ & $(0.013)$ & $(0.011)$ & $(0.011)$ \\
\hline \multirow[t]{2}{*}{ MTenure } & $-0.158^{* * *}$ & $-0.167^{* * *}$ & $-0.157^{* * *}$ & $-0.154^{* * *}$ & $-0.165^{* * *}$ & $-0.164^{* * *}$ \\
\hline & $(0.046)$ & $(0.050)$ & $(0.045)$ & $(0.045)$ & $(0.043)$ & $(0.043)$ \\
\hline \multirow[t]{2}{*}{ MEconomist } & 0.192 & 0.268 & 0.201 & 0.223 & 0.209 & 0.205 \\
\hline & $(0.167)$ & $(0.178)$ & $(0.170)$ & $(0.171)$ & (0.158) & $(0.157)$ \\
\hline \multirow[t]{2}{*}{ MLawyers } & -0.227 & -0.129 & -0.177 & -0.188 & -0.110 & -0.112 \\
\hline & $(0.244)$ & $(0.246)$ & $(0.251)$ & $(0.254)$ & $(0.238)$ & $(0.237)$ \\
\hline \multirow[t]{2}{*}{ MWoman } & 0.108 & 0.016 & 0.090 & 0.085 & 0.121 & 0.119 \\
\hline & $(0.184)$ & $(0.192)$ & $(0.196)$ & $(0.196)$ & $(0.189)$ & $(0.188)$ \\
\hline \multirow[t]{2}{*}{ MSize } & $-0.229^{* *}$ & $-0.199^{*}$ & -0.178 & -0.168 & $-0.216^{* *}$ & $-0.217^{* *}$ \\
\hline & $(0.103)$ & $(0.115)$ & $(0.112)$ & (0.113) & $(0.088)$ & $(0.089)$ \\
\hline \multirow[t]{2}{*}{ MInsiders } & -0.204 & $-0.268^{*}$ & $-0.236^{*}$ & -0.224 & $-0.240^{*}$ & $-0.238^{*}$ \\
\hline & $(0.137)$ & $(0.138)$ & $(0.137)$ & $(0.141)$ & $(0.137)$ & $(0.137)$ \\
\hline \multirow[t]{2}{*}{ Lag Return } & -0.600 & & & & & \\
\hline & $(1.557)$ & & & & & \\
\hline \multirow[t]{2}{*}{ Lag Sharp } & & -0.105 & & & & \\
\hline & & $(0.112)$ & & & & \\
\hline \multirow[t]{2}{*}{ Lag ROE } & & & -0.013 & & & \\
\hline & & & $(0.015)$ & & & \\
\hline \multirow[t]{2}{*}{ Lag ROA } & & & & -0.058 & & \\
\hline & & & & $(0.049)$ & & \\
\hline \multirow[t]{2}{*}{ DOE } & & & & & 0.539 & \\
\hline & & & & & $(0.330)$ & \\
\hline \multirow[t]{2}{*}{ DOA } & & & & & & 0.590 \\
\hline & & & & & & $(0.375)$ \\
\hline Obs. & 173 & 163 & 168 & 168 & 188 & 188 \\
\hline
\end{tabular}

Note: Estimation presents the marginal effects at means of the independent variable after the regressions are run by Logit model. All specifications include year dummies. Variables definitions are in Table 1. Robust standard errors are reported in parentheses. ${ }^{* *},{ }^{* *}$ and * indicate significance at 1, 5, and 10 percent levels, respectively. 
Another sign of potential problems with the internal mechanism is the lack of any significant variables explaining the turnover of the Chairman, which is presented in Table 11. As almost all coefficients are close to zero, it shows that the role of the Chairman is very weak and is neither related to the performance, its characteristics, or ownership of the fund. Hence, the results indicate problems in the fund's governance, as the Chairman organizes the work of the board and prepares the agenda for the meetings. Consequently, it is often his initiative to replace managers if the firm is underperforming over a longer period. Moreover, Jenter and Lewellen (2010) have documented that strong boards are more likely to replace their CEOs than weaker boards, at least in the beginning of tenure. Hence, those results may also explain the low likelihood of replacing managers in the first years of their tenure.

Table 11. Chairman turnover and past pension fund performance

\begin{tabular}{|c|c|c|c|c|c|c|}
\hline & (1) & (2) & (3) & (4) & (5) & (6) \\
\hline \multirow[t]{2}{*}{ Government } & 0.000 & -0.000 & 0.000 & 0.000 & 0.000 & 0.000 \\
\hline & $(0.001)$ & $(0.001)$ & $(0.001)$ & $(0.001)$ & $(0.001)$ & $(0.001)$ \\
\hline \multirow[t]{2}{*}{ Domestic } & 0.002 & 0.006 & 0.004 & 0.004 & 0.003 & 0.003 \\
\hline & $(0.005)$ & $(0.014)$ & (0.009) & (0.009) & $(0.007)$ & $(0.007)$ \\
\hline \multirow[t]{2}{*}{ Foreign } & -0.000 & -0.000 & -0.000 & -0.000 & -0.000 & -0.000 \\
\hline & $(0.001)$ & $(0.001)$ & $(0.001)$ & $(0.001)$ & $(0.001)$ & $(0.001)$ \\
\hline \multirow[t]{2}{*}{ Shareholders } & -0.000 & -0.000 & -0.000 & -0.000 & -0.000 & -0.000 \\
\hline & $(0.000)$ & $(0.000)$ & $(0.000)$ & $(0.000)$ & $(0.000)$ & $(0.000)$ \\
\hline \multirow[t]{2}{*}{ CBTenure } & -0.001 & -0.002 & -0.001 & -0.001 & -0.002 & -0.002 \\
\hline & $(0.004)$ & $(0.004)$ & (0.004) & $(0.004)$ & $(0.004)$ & $(0.004)$ \\
\hline \multirow[t]{2}{*}{ CBIndependent } & 0.000 & 0.000 & 0.000 & 0.000 & 0.000 & 0.000 \\
\hline & $(0.000)$ & $(0.000)$ & $(0.000)$ & $(0.000)$ & $(0.000)$ & $(0.000)$ \\
\hline \multirow[t]{2}{*}{ CBEconomist } & -0.000 & -0.000 & -0.000 & -0.000 & -0.000 & -0.000 \\
\hline & $(0.000)$ & $(0.000)$ & $(0.000)$ & $(0.000)$ & $(0.000)$ & $(0.000)$ \\
\hline \multirow[t]{2}{*}{ CBAge } & -0.000 & 0.000 & -0.000 & -0.000 & -0.000 & -0.000 \\
\hline & $(0.000)$ & $(0.000)$ & $(0.000)$ & $(0.000)$ & $(0.000)$ & $(0.000)$ \\
\hline \multirow[t]{2}{*}{ Lag Return } & 0.002 & & & & & \\
\hline & $(0.005)$ & & & & & \\
\hline \multirow[t]{2}{*}{ Lag Sharp } & & 0.000 & & & & \\
\hline & & $(0.000)$ & & & & \\
\hline \multirow[t]{2}{*}{ Lag ROE } & & & 0.000 & & & \\
\hline & & & $(0.000)$ & & & \\
\hline \multirow[t]{2}{*}{ Lag ROA } & & & & 0.000 & & \\
\hline & & & & $(0.000)$ & & \\
\hline \multirow[t]{2}{*}{ DOE } & & & & & -0.000 & \\
\hline & & & & & $(0.000)$ & \\
\hline \multirow[t]{2}{*}{$\mathrm{DOA}$} & & & & & & -0.000 \\
\hline & & & & & & $(0.000)$ \\
\hline Obs. & 159 & 149 & 154 & 154 & 158 & 158 \\
\hline
\end{tabular}

Note: Estimation presents the marginal effects at means of the independent variable after the regressions are run by Logit model. All specifications include year dummies. Variables definitions are in Table 1. Robust standard errors are reported in parentheses. ${ }^{* * *},{ }^{* *}$ and ${ }^{*}$ indicate significance at 1,5, and 10 percent levels, respectively. 
The results in Table 12 confirm the previous finding, showing that the changes in board members are also not related to its performance. Consequently, they document the weakness of the board as an internal governance mechanism in the pension funds, which may also explain the insignificance of some of the variables in the prior board structure regressions.

The results, however, present that the likelihood of board dismissal increases if the board member is a foreigner or if they hold multiple shares. An explanation for those results is the practice by foreign shareholders of delegating board members for a short term, which may often be related to their other position in the host or home country. Those results are strengthened by the fact that only domestic pension funds have stable boards. In the case of multiple shareholders, the increased likelihood of turnover can be the result of an agreement on rotation by the board members in the fund as well a consequence of changes in the ownership structure.

The estimates also indicate that owners are more likely to dismiss outsiders, yet not at the beginning of their tenure. Hence, the results suggest that the position of the outsiders is rather weak in the pension funds. However, the replacement of the board members is more likely if the board is large. An explanation for this result can be the scaled down process of the size of the boards observed in almost all pension funds over time. Nevertheless, it does not mean an improvement of its governance, as size was not related to any performance measures in the previous regressions. An explanation for this result can be that changes are more likely to occur if the dismissal of the board members does not lead to regulatory problems related to its small size.

Table 12. Board Member turnover and past pension fund performance

\begin{tabular}{|c|c|c|c|c|c|c|}
\hline & (1) & (2) & (3) & (4) & (5) & (6) \\
\hline \multirow[t]{2}{*}{ Government } & 0.034 & -0.013 & -0.007 & 0.016 & 0.007 & 0.009 \\
\hline & $(0.203)$ & $(0.224)$ & $(0.205)$ & $(0.217)$ & $(0.201)$ & $(0.201)$ \\
\hline \multirow[t]{2}{*}{ Domestic } & -0.301 & -0.336 & $-0.326^{*}$ & -0.324 & $-0.303^{*}$ & $-0.301^{*}$ \\
\hline & $(0.200)$ & $(0.206)$ & $(0.189)$ & $(0.205)$ & $(0.161)$ & $(0.162)$ \\
\hline \multirow[t]{2}{*}{ Foreign } & -0.036 & -0.082 & -0.072 & -0.065 & -0.080 & -0.083 \\
\hline & (0.194) & $(0.205)$ & $(0.183)$ & $(0.202)$ & $(0.188)$ & $(0.188)$ \\
\hline \multirow[t]{2}{*}{ Shareholders } & $0.087^{*}$ & $0.104^{*}$ & $0.115^{* *}$ & $0.107^{* *}$ & $0.107^{* *}$ & $0.105^{* *}$ \\
\hline & $(0.047)$ & $(0.057)$ & $(0.053)$ & $(0.051)$ & $(0.049)$ & $(0.049)$ \\
\hline \multirow[t]{2}{*}{ BSize } & $0.065^{*}$ & 0.064 & $0.068^{*}$ & $0.065^{*}$ & $0.080^{* *}$ & $0.079^{* *}$ \\
\hline & $(0.036)$ & $(0.042)$ & $(0.038)$ & $(0.038)$ & $(0.039)$ & $(0.039)$ \\
\hline \multirow[t]{2}{*}{ BForeigners } & $0.493^{* *}$ & $0.713^{* * *}$ & $0.583^{* *}$ & $0.566^{* *}$ & $0.495^{* *}$ & $0.497^{* *}$ \\
\hline & $(0.236)$ & $(0.272)$ & $(0.261)$ & $(0.250)$ & $(0.228)$ & $(0.228)$ \\
\hline \multirow[t]{2}{*}{ BWoman } & 0.243 & 0.500 & 0.454 & 0.399 & 0.248 & 0.235 \\
\hline & (0.399) & $(0.442)$ & $(0.440)$ & $(0.438)$ & (0.399) & $(0.400)$ \\
\hline \multirow[t]{2}{*}{ BAge } & -0.013 & -0.008 & -0.010 & -0.009 & -0.011 & -0.011 \\
\hline & $(0.010)$ & $(0.011)$ & $(0.010)$ & $(0.010)$ & (0.009) & (0.009) \\
\hline \multirow[t]{2}{*}{ BOutsiders } & 0.449 & 0.654 & $0.826^{*}$ & $0.754^{*}$ & 0.346 & 0.348 \\
\hline & (0.394) & $(0.451)$ & $(0.434)$ & $(0.401)$ & $(0.379)$ & (0.379) \\
\hline \multirow[t]{2}{*}{ BlTenure } & $-0.058^{*}$ & $-0.060^{*}$ & $-0.069^{* *}$ & $-0.067^{*}$ & $-0.058^{*}$ & $-0.058^{*}$ \\
\hline & $(0.034)$ & $(0.034)$ & $(0.035)$ & $(0.035)$ & $(0.034)$ & $(0.035)$ \\
\hline
\end{tabular}


Table 12. (continued)

\begin{tabular}{|c|c|c|c|c|c|c|}
\hline & (1) & (2) & (3) & (4) & (5) & (6) \\
\hline \multirow[t]{2}{*}{ Lag Return } & 0.304 & & & & & \\
\hline & $(1.817)$ & & & & & \\
\hline \multirow[t]{2}{*}{ Lag Sharp } & & 0.116 & & & & \\
\hline & & (0.138) & & & & \\
\hline \multirow[t]{2}{*}{ Lag ROE } & & & -0.026 & & & \\
\hline & & & (0.016) & & & \\
\hline \multirow[t]{2}{*}{ Lag ROA } & & & & 0.036 & & \\
\hline & & & & $(0.048)$ & & \\
\hline \multirow[t]{2}{*}{ DOE } & & & & & -0.113 & \\
\hline & & & & & $(0.412)$ & \\
\hline \multirow[t]{2}{*}{ DOA } & & & & & & -0.041 \\
\hline & & & & & & $(0.484)$ \\
\hline Obs. & 173 & 163 & 168 & 168 & 188 & 188 \\
\hline
\end{tabular}

Note: Estimation presents the marginal effects at means of the independent variable after the regressions are run by Logit model. All specifications include year dummies. Variables definitions are in Table 1. Robust standard errors are reported in parentheses. ${ }^{* *},{ }^{* *}$ and ${ }^{*}$ indicate significance at 1,5 , and 10 percent levels, respectively.

\subsection{Other governance factors}

\subsubsection{Ownership}

Berger et al. (2005) showed that ownership may be a proxy for governance in the banking industry. Following their approach, I distinguish three different types of ownership: domestic, foreign, and stateowned. In some of the pension funds, two different types of owners were present at the same time, both of which had a share of $50 \%$ of the fund's equity. In those funds, the ownership dummy variable took a value of one for each different type of owner. Moreover, the variable shareholder is employed to control for the number of owners in the pension funds.

The results in Table 13 show that foreign ownership is significant and positively associated with the Sharp ratio and ROA, while the results for the unit return and the Sharp ratio for government and domestically owned funds are less conclusive. Turning next to the effect of multiple shareholders, the results show a positive and significant effect on dividend payout policy, which is consistent with the literature. The coefficient, however, is insignificant in the remaining specification. One explanation for the results is that having multiple share- holders has a negative impact on the functioning and monitoring of the boards in pension funds and, therefore, on the managers. At the same time, as in case of multiple shareholders, none of the owners control the boards so they are interested in extracting high rents in the form of dividends, which may explain why the coefficients are insignificant in the remaining specifications.

\subsubsection{Pension fund activism}

The recent movement in corporate governance resulted in many countries adopting regulations that require pension funds to disclose their voting praxis. In Poland, a mandatory voting disclosure requirement for pension funds has existed since 2005. Prior to this date, the funds did not disclose how they voted on behalf of their investors. Moreover, in the same period, some of the funds accepted additional governance codes in which their general voting policy is disclosed. Acceptance of those codes and the participation in a general meeting is used as an additional proxy for governance in pension funds, whereas it is expected that both factors are positively related to their performance (Guercio \& Hawkins, 1999). 
Table 13. Ownership and pension fund performance

\begin{tabular}{|c|c|c|c|c|c|c|c|c|c|c|}
\hline & \multicolumn{4}{|l|}{ OLS } & \multicolumn{4}{|c|}{ Fixed effects } & \multicolumn{2}{|l|}{ Tobit } \\
\hline & Return & Sharp & ROE & $\mathrm{ROA}$ & Return & Sharp & ROE & $\mathrm{ROA}$ & DOE & DOA \\
\hline \multirow[t]{2}{*}{ Government } & 0.005 & $0.377^{*}$ & -1.237 & -0.183 & $0.024^{*}$ & 0.244 & -0.070 & -0.631 & 0.128 & 0.092 \\
\hline & $(0.016)$ & (0.198) & $(0.906)$ & $(0.259)$ & $(0.012)$ & $(0.256)$ & $(1.069)$ & $(0.485)$ & $(1.021)$ & $(0.835)$ \\
\hline \multirow[t]{2}{*}{ Domestic } & $0.026^{*}$ & 0.408 & 0.918 & -0.040 & 0.012 & 0.388 & -0.506 & -0.173 & 0.202 & 0.176 \\
\hline & $(0.016)$ & $(0.254)$ & $(1.558)$ & $(0.332)$ & $(0.007)$ & $(0.245)$ & $(1.177)$ & $(0.365)$ & (1.013) & $(0.828)$ \\
\hline \multirow[t]{2}{*}{ Foreign } & 0.012 & $0.439 * *$ & -0.578 & 0.149 & 0.012 & $0.508^{* *}$ & -0.897 & $0.879 * *$ & 0.281 & 0.211 \\
\hline & $(0.014)$ & $(0.197)$ & $(0.955)$ & $(0.269)$ & $(0.014)$ & $(0.176)$ & $(0.853)$ & $(0.351)$ & $(1.021)$ & $(0.835)$ \\
\hline \multirow[t]{2}{*}{ Shareholders } & 0.000 & 0.045 & -0.062 & -0.019 & 0.010 & 0.037 & 1.262 & -0.376 & $0.105^{* *}$ & $0.091^{* *}$ \\
\hline & $(0.002)$ & $(0.040)$ & $(0.280)$ & $(0.060)$ & $(0.007)$ & $(0.136)$ & $(0.866)$ & $(0.260)$ & $(0.045)$ & $(0.036)$ \\
\hline \multirow[t]{2}{*}{ Assets } & 0.003 & 0.002 & 1.207 & 0.227 & 0.010 & -0.266 & -0.474 & -0.353 & 0.179 & 0.187 \\
\hline & $(0.003)$ & $(0.029)$ & $(1.291)$ & $(0.236)$ & $(0.011)$ & $(0.207)$ & $(1.321)$ & $(0.257)$ & $(0.222)$ & $(0.181)$ \\
\hline \multirow[t]{2}{*}{ Members } & & & -1.261 & -0.045 & & & -2.875 & $-0.711^{* *}$ & 0.002 & -0.033 \\
\hline & & & $(1.771)$ & $(0.284)$ & & & $(2.417)$ & $(0.288)$ & $(0.278)$ & $(0.227)$ \\
\hline Obs. & 194 & 180 & 188 & 188 & 194 & 180 & 188 & 188 & 118 & 118 \\
\hline Firms & 21 & 17 & 21 & 21 & 21 & 17 & 21 & 21 & 16 & 16 \\
\hline $\mathrm{R}^{2}$ & 0.89 & 0.90 & 0.12 & 0.46 & 0.90 & 0.93 & 0.14 & 0.49 & & \\
\hline
\end{tabular}

Note: Regressions are run by OLS, and the fixed-effects model, and the Tobit model. Variables definitions are in Table 1. OLS specifications include firm fixed effects and all specifications include year dummies. Robust standard errors are reported in parentheses. ${ }^{* *},{ }^{* *}$ and ${ }^{*}$ indicate significance at 1,5 , and 10 percent levels, respectively.

Table 14. Pension fund activism and pension fund performance

\begin{tabular}{lllll|llll|lll}
\hline & OLS & & & & \multicolumn{2}{l}{ Fixed effects } & & \multicolumn{2}{l}{ Tobit } \\
& Return & Sharp & ROE & ROA & Return & Sharp & ROE & ROA & DOE & DOA \\
\hline CG inv & -0.001 & 0.301 & -0.077 & -0.052 & $-0.014^{* *}$ & 0.069 & $-0.242^{* *}$ & $-0.192^{* *}$ & -0.104 & -0.081 \\
& $(0.007)$ & $(0.262)$ & $(0.181)$ & $(0.150)$ & $(0.005)$ & $(0.186)$ & $(0.091)$ & $(0.072)$ & $(0.109)$ & $(0.091)$ \\
GM no & -0.025 & -0.533 & 0.035 & 0.053 & -0.016 & $-0.592^{*}$ & 0.008 & 0.016 & $0.466^{*}$ & $0.378^{*}$ \\
& $(0.021)$ & $(0.403)$ & $(0.205)$ & $(0.170)$ & $(0.023)$ & $(0.302)$ & $(0.084)$ & $(0.069)$ & $(0.249)$ & $(0.209)$ \\
GM co & 0.052 & 0.807 & 0.344 & 0.232 & 0.041 & 0.683 & 0.035 & 0.018 & -0.546 & -0.464 \\
& $(0.039)$ & $(0.803)$ & $(0.469)$ & $(0.389)$ & $(0.046)$ & $(0.987)$ & $(0.203)$ & $(0.168)$ & $(0.432)$ & $(0.363)$ \\
Equity & -0.005 & -0.849 & 0.760 & 0.801 & -0.177 & -2.576 & -0.334 & -0.126 & -0.699 & -0.615 \\
& $(0.143)$ & $(1.519)$ & $(0.969)$ & $(0.835)$ & $(0.159)$ & $(2.112)$ & $(0.483)$ & $(0.374)$ & $(1.361)$ & $(1.146)$ \\
Assets & -0.002 & -0.097 & -0.088 & -0.094 & 0.005 & 0.070 & $-0.812^{* * *}$ & $-0.614^{* * *}$ & 0.078 & 0.122 \\
& $(0.004)$ & $(0.087)$ & $(0.102)$ & $(0.094)$ & $(0.012)$ & $(0.277)$ & $(0.238)$ & $(0.174)$ & $(0.288)$ & $(0.247)$ \\
Members & & & 0.171 & 0.175 & & & $0.645^{* *}$ & $0.507^{* *}$ & 0.083 & 0.016 \\
& & & $(0.118)$ & $(0.110)$ & & & $(0.244)$ & $(0.180)$ & $(0.366)$ & $(0.314)$ \\
\hline Obs & 85 & 85 & 85 & 85 & 85 & 85 & 85 & 85 & 85 & 85 \\
Firms & 21 & 17 & 21 & 21 & 14 & 14 & 14 & 14 & 14 & 14 \\
R2 & 0.98 & 0.97 & 0.45 & 0.48 & 0.98 & 0.97 & 0.66 & 0.66 & &
\end{tabular}

Note: Regressions are run by OLS, and the fixed-effects model, and the Tobit model. Variables definitions are in Table 1. OLS specifications include firm fixed effects and all specifications include year dummies. Robust standard errors are reported in parentheses. ${ }^{* *},{ }^{* *}$ and ${ }^{*}$ indicate significance at 1,5 , and 10 percent levels, respectively. 
In Table 14, the results reveal that accepting a governance code is significant and negatively related to the return on the pension unit as well as to the ROE and ROA. The results are inconsistent with the idea that disclosure of good practices is associated with positive performance. Furthermore, the results show that the general presence of pension funds at annual meetings do not translate to positive returns for beneficiaries and the owner. An explanation for this result can be that the activism of funds is low in Poland. The assumption is strengthened by the data in Table 1 that show that a large number of funds representatives do not attend shareholder meetings at all. Furthermore, a more detailed study of the funds' proxies revealed, for example, that representatives of state-owned funds participated mainly in the meetings of listed companies where the government was owner as well. Hence, the shareholder activism in funds may often be attributed to factors other than increasing the wealth of beneficiaries.

Surprisingly, the results show that pension fund activism is significant and positively related with the two dividend payout ratios. An explanation for these results can be that funds representatives who are activ- ists try to extract dividends payments in the invested companies, which reflects their own company policy. The sample data, however, do not allow us to test this hypothesis and therefore this phenomenon is left for future research.

\subsubsection{Auditor rotation}

After the failures of Enron and Arthur Andersen, auditor rotation was seen as a good corporate practice in many listed companies. Also in the pension funds industry it has been emphasized that the external auditor may be a key feature of its governance but only when their work is not done mechanically (Besley \& Prat, 2003). In pension funds, auditor rotation is not obligatory; hence, it may be a good proxy for governance. As auditor change may also be a result of a takeover or a merger in the regression, a control variable is used that equals one when the fund has merged or acquired another entity.

The results in Table 15 reveal that auditor changes have a positive impact on pension unit return but that it is insignificant. Moreover, I find that the changes of the auditor do not have a statistically significant effect on pension fund profitability or its dividend policy.

Table 15. Auditor change and pension fund performance

\begin{tabular}{lllll|lllll|l}
\hline & OLS & & & & & & & & & \multicolumn{2}{l}{ Tobit } \\
& Return & Sharp & ROE & ROA & Return & Sharp & ROE & ROA & DOE & DOA \\
\hline Audit & 0.005 & 0.037 & -0.149 & 0.030 & 0.001 & 0.086 & 0.178 & 0.177 & -0.003 & 0.010 \\
& $(0.007)$ & $(0.087)$ & $(0.309)$ & $(0.149)$ & $(0.006)$ & $(0.072)$ & $(0.313)$ & $(0.177)$ & $(0.083)$ & $(0.069)$ \\
M\&A & -0.001 & -0.066 & -1.396 & -0.897 & -0.005 & 0.005 & -1.143 & -0.806 & -0.789 & -0.905 \\
& $(0.012)$ & $(0.158)$ & $(0.951)$ & $(0.697)$ & $(0.013)$ & $(0.175)$ & $(0.789)$ & $(0.749)$ & $(69.930)$ & $(1.1 e+04)$ \\
Assets & 0.002 & -0.001 & 0.958 & 0.266 & 0.011 & -0.270 & -0.280 & -0.432 & 0.118 & 0.134 \\
& $(0.003)$ & $(0.028)$ & $(1.264)$ & $(0.217)$ & $(0.011)$ & $(0.208)$ & $(1.374)$ & $(0.288)$ & $(0.235)$ & $(0.198)$ \\
Members & & & -1.118 & -0.096 & & & -3.249 & -0.416 & 0.054 & 0.014 \\
& & & $(1.662)$ & $(0.271)$ & & & $(2.321)$ & $(0.312)$ & $(0.294)$ & $(0.248)$ \\
\hline Obs & 194 & 180 & 188 & 188 & 194 & 180 & 188 & 188 & 118 & 118 \\
Firms & 21 & 17 & 21 & 21 & 21 & 17 & 21 & 21 & 16 & 16 \\
R² & 0.89 & 0.90 & 0.09 & 0.47 & 0.90 & 0.92 & 0.12 & 0.45 & &
\end{tabular}

Note: Regressions are run by OLS, and the fixed-effects model, and the Tobit model. Variables definitions are in Table 1. OLS specifications include firm fixed effects and all specifications include year dummies. Robust standard errors are reported in parentheses. ${ }^{* *},{ }^{* *}$ and ${ }^{*}$ indicate significance at 1,5 , and 10 percent levels, respectively. 


\subsubsection{Pension fund behavior}

Another sign of governance practices in pension funds may be the disclosure of ethics codes for senior managers but more important is the lack of corporate fraud. In this study corporate fraud is measured by two variables showing the number and value of fines imposed on the funds by the regulator.

The results in Table 16 suggest that the incorporation of an ethics code by pension funds is negatively related to ROA, yet the coefficient is significant only in the OLS regression. In this regression, the coefficient is significantly and negatively related to ROE too, but has an inverse sign in the fixed effects regressions. An explanation for those results can be that the ethic codices have been adapted only recently.

Hence, two other variables can provide more information on a pension fund's behavior. I find that the number of fines imposed on the funds is significant and negatively related to the pension unit return, the Sharp ratio, and the two dividend payout ratios. Those results are in line with the literature showing that the initial disclosure of illegal corporate activities results in significant negative abnormal returns to the share- holders (Karpoff \& Lott, 1993). Chen et al. (2006) also found that a higher proportion of outside directors is associated with a lower probability of fraud. Similarly, Park and Shin (2004) have suggested that the ineffectiveness of governance mechanisms may be the result of high ownership concentration and the underdeveloped market for outside directors in Canada. Those two studies indicate that unethical acts are associated with ineffectiveness of corporate governance related to outsiders and may explain why fines are negatively related to the performance measures.

In contrast, the coefficient showing that the value of fines is significant and positively related to the pension unit's return and to the Sharp ratio, too. An explanation for this result is that high fines are often imposed as a result of stock manipulation by pension managers. As a consequence, the gains of illegal and unethical acts are here linked with profit for pension beneficiaries. While the pension managers pursue the goal of assets maximization, their incentives are more likely to be related to their remunerations and, henceforth, are not seen as signs of strong governance in the funds.

Table 16. Corporate behavior and pension fund performance

\begin{tabular}{|c|c|c|c|c|c|c|c|c|c|c|}
\hline & \multicolumn{4}{|l|}{ OLS } & \multicolumn{4}{|c|}{ Fixed-effects } & \multicolumn{2}{|l|}{ Tobit } \\
\hline & Return & Sharp & $\mathrm{ROE}$ & $\mathrm{ROA}$ & Return & Sharp & $\mathrm{ROE}$ & $\mathrm{ROA}$ & DOE & DOA \\
\hline \multirow[t]{2}{*}{ Ethics } & 0.003 & 0.116 & $-0.421^{*}$ & $-0.190^{* *}$ & -0.000 & 0.211 & $0.756^{* *}$ & -0.149 & $-0.250^{*}$ & $-0.203^{*}$ \\
\hline & $(0.003)$ & $(0.073)$ & $(0.234)$ & $(0.090)$ & $(0.005)$ & $(0.128)$ & $(0.360)$ & $(0.126)$ & $(0.139)$ & $(0.115)$ \\
\hline \multirow[t]{2}{*}{ Fine no } & $-0.012^{* * *}$ & $-0.170^{* *}$ & -0.283 & 0.101 & $-0.010^{* *}$ & $-0.168^{*}$ & 0.009 & 0.165 & $-0.134^{*}$ & $-0.115^{*}$ \\
\hline & $(0.004)$ & $(0.066)$ & $(0.361)$ & $(0.114)$ & $(0.004)$ & $(0.090)$ & $(0.252)$ & $(0.116)$ & $(0.071)$ & $(0.060)$ \\
\hline \multirow[t]{2}{*}{ Fine value } & $0.002^{* * *}$ & $0.024^{* *}$ & 0.076 & -0.013 & $0.002^{* *}$ & $0.024^{*}$ & 0.068 & -0.013 & 0.006 & 0.006 \\
\hline & $(0.001)$ & $(0.011)$ & $(0.084)$ & $(0.015)$ & $(0.001)$ & $(0.013)$ & $(0.064)$ & $(0.021)$ & $(0.008)$ & $(0.007)$ \\
\hline \multirow[t]{2}{*}{ Assets } & 0.002 & 0.009 & 1.140 & 0.328 & 0.009 & -0.254 & -0.409 & -0.415 & 0.138 & 0.158 \\
\hline & $(0.003)$ & $(0.029)$ & $(1.227)$ & $(0.230)$ & $(0.011)$ & $(0.224)$ & $(1.454)$ & $(0.311)$ & $(0.230)$ & $(0.194)$ \\
\hline \multirow[t]{2}{*}{ Members } & & & -1.358 & -0.183 & & & -3.687 & $-0.651^{*}$ & 0.038 & -0.009 \\
\hline & & & $(1.607)$ & $(0.303)$ & & & $(2.347)$ & $(0.330)$ & $(0.285)$ & $(0.240)$ \\
\hline Obs & 194 & 180 & 188 & 188 & 194 & 180 & 188 & 188 & 118 & 118 \\
\hline Firms & 21 & 17 & 21 & 21 & 21 & 17 & 21 & 21 & 16 & 16 \\
\hline$R^{2}$ & 0.89 & 0.90 & 0.09 & 0.45 & 0.91 & 0.93 & 0.14 & 0.44 & & \\
\hline
\end{tabular}

Note: Regressions are run by OLS, and the fixed-effects model, and the Tobit model. Variables definitions are in Table 1. OLS specifications include firm fixed effects and all specifications include year dummies. Robust standard errors are reported in parentheses. ${ }^{* * *},{ }^{* *}$ and ${ }^{*}$ indicate significance at 1, 5, and 10 percent levels, respectively. 


\subsection{Corporate governance indices}

Evidence from prior regressions indicates that some governance factors may determine the pension fund's performance. Those factors, which in those regressions were significant, are used in order to create three indices. The indices are broad summary measures of governance for a pension unit's return, its profitability (ROA), and dividend policy (DOA). The first index includes eight governance factors, where each factor is coded 1 (or 0 ) if it does (or does not) represent accept- able governance. The second and third index includes 13 and 12 factors, respectively. Those factors cover the four governance categories: the board characteristics, shareholder structure, fund activism, and behavior.

Table 17 shows the results for the three CG indices and, as expected, each of them is significantly and positively related to the specified performance measure. At the same time, each of the CG indices is correlated only with the predicted performance measures but is insignificant in other specification.

Table 17. Corporate governance index and pension fund performance

\begin{tabular}{|c|c|c|c|c|c|c|c|c|c|c|}
\hline & \multicolumn{4}{|l|}{ OLS } & \multicolumn{4}{|c|}{ Fixed-effects } & \multicolumn{2}{|l|}{ Tobit } \\
\hline & Return & Sharp & $\mathrm{ROE}$ & $\mathrm{ROA}$ & Return & Sharp & ROE & $\mathrm{ROA}$ & DOE & DOA \\
\hline \multicolumn{11}{|c|}{ Corporate index for return on pension unit } \\
\hline \multirow[t]{2}{*}{ CG index } & $0.053^{* *}$ & $0.582^{*}$ & 0.432 & $1.191^{*}$ & $0.036^{* *}$ & 0.516 & -0.062 & $1.572^{*}$ & 0.011 & -0.015 \\
\hline & $(0.022)$ & $(0.320)$ & $(2.499)$ & $(0.714)$ & $(0.017)$ & $(0.316)$ & $(2.552)$ & $(0.795)$ & $(0.263)$ & $(0.222)$ \\
\hline \multirow[t]{2}{*}{ Assets } & 0.004 & 0.018 & 1.046 & 0.299 & 0.012 & -0.249 & -0.284 & -0.426 & 0.132 & 0.146 \\
\hline & $(0.003)$ & $(0.030)$ & $(1.239)$ & $(0.217)$ & $(0.012)$ & $(0.218)$ & $(1.357)$ & $(0.289)$ & $(0.238)$ & $(0.201)$ \\
\hline \multirow[t]{2}{*}{ Members } & & & -1.196 & -0.085 & & & -3.493 & -0.560 & 0.031 & -0.007 \\
\hline & & & $(1.667)$ & $(0.281)$ & & & $(2.318)$ & $(0.331)$ & $(0.297)$ & $(0.251)$ \\
\hline \multicolumn{11}{|c|}{ Corporate index for $\mathrm{ROA}$} \\
\hline \multirow[t]{2}{*}{ CG index } & 0.005 & 0.093 & 0.894 & $0.854^{*}$ & -0.001 & 0.294 & $3.546^{* * *}$ & $1.374^{* * *}$ & -0.177 & -0.159 \\
\hline & $(0.020)$ & $(0.261)$ & $(1.480)$ & $(0.481)$ & $(0.013)$ & $(0.285)$ & $(0.947)$ & $(0.436)$ & $(0.205)$ & $(0.172)$ \\
\hline \multirow[t]{2}{*}{ Assets } & 0.002 & -0.004 & 1.005 & 0.274 & 0.011 & -0.247 & -0.244 & -0.408 & 0.119 & 0.137 \\
\hline & $(0.003)$ & $(0.028)$ & $(1.184)$ & $(0.209)$ & $(0.011)$ & $(0.212)$ & $(1.336)$ & $(0.302)$ & $(0.234)$ & $(0.197)$ \\
\hline \multirow[t]{2}{*}{ Members } & & & -1.170 & -0.110 & & & -3.378 & $-0.544^{*}$ & 0.044 & 0.003 \\
\hline & & & $(1.580)$ & $(0.266)$ & & & $(2.218)$ & $(0.267)$ & $(0.293)$ & $(0.248)$ \\
\hline \multicolumn{11}{|c|}{ Corporate index for DOA } \\
\hline \multirow[t]{2}{*}{ CG index } & -0.008 & 0.150 & 1.164 & 0.032 & -0.008 & -0.253 & -0.280 & -0.637 & $0.368^{*}$ & $0.306^{*}$ \\
\hline & $(0.016)$ & $(0.251)$ & $(1.116)$ & $(0.444)$ & $(0.023)$ & $(0.473)$ & $(1.178)$ & $(0.474)$ & $(0.209)$ & $(0.175)$ \\
\hline \multirow[t]{2}{*}{ Assets } & 0.002 & -0.007 & 1.014 & 0.319 & 0.010 & -0.264 & -0.298 & -0.454 & 0.131 & 0.143 \\
\hline & $(0.003)$ & $(0.028)$ & $(1.223)$ & $(0.219)$ & $(0.011)$ & $(0.222)$ & $(1.377)$ & $(0.290)$ & $(0.230)$ & $(0.195)$ \\
\hline \multirow[t]{2}{*}{ Members } & & & -1.208 & -0.161 & & & -3.506 & $-0.619^{*}$ & 0.019 & -0.014 \\
\hline & & & (1.620) & $(0.274)$ & & & (2.313) & $(0.304)$ & $(0.288)$ & $(0.244)$ \\
\hline Obs. & 194 & 180 & 188 & 188 & 194 & 180 & 188 & 188 & 118 & 118 \\
\hline Firms & 21 & 17 & 21 & 21 & 21 & 17 & 21 & 21 & 16 & 16 \\
\hline
\end{tabular}

Note: Regressions are run by OLS, and the fixed-effects model, and the Tobit model. Variables definitions are in Table 1. OLS specifications include firm fixed effects and all specifications include year dummies. Robust standard errors are reported in parentheses. ${ }^{* *},{ }^{* *}$ and ${ }^{*}$ indicate significance at 1,5 , and 10 percent levels, respectively. 
Using principal components analysis, those three as well as two CG indices are combined into one CG index to analyze whether the governance factors, which are either important for the pension fund beneficiaries or its owners, can be combined into one. In Table 18, the results show that combining the CG indices for the pension unit return with the other two indices leads to loosing the ability to predict any measure for fund performance. Combining the two CG indices for funds profitability and dividend payout produces weak but still statistically significant results. Hence, the result suggests that different governance factors are important for beneficiaries than for owners, which confirms the assumption of the Besley and Prat model.

Table 18. Combined corporate governance index and pension fund performance

\begin{tabular}{|c|c|c|c|c|c|c|c|c|c|c|}
\hline & \multicolumn{4}{|l|}{ OLS } & \multicolumn{4}{|c|}{ Fixed-effects } & \multicolumn{2}{|l|}{ Tobit } \\
\hline & Return & Sharp & ROE & $\mathrm{ROA}$ & Return & Sharp & $\mathrm{ROE}$ & $\mathrm{ROA}$ & DOE & DOA \\
\hline \multicolumn{11}{|c|}{ Corporate governance index for pension unit return, ROA and DOA } \\
\hline \multirow[t]{2}{*}{ CG index } & -0.002 & -0.005 & 0.109 & 0.007 & -0.002 & -0.020 & 0.184 & -0.029 & 0.016 & 0.013 \\
\hline & $(0.002)$ & $(0.025)$ & $(0.130)$ & $(0.046)$ & $(0.002)$ & $(0.047)$ & $(0.129)$ & $(0.058)$ & $(0.023)$ & $(0.020)$ \\
\hline \multicolumn{11}{|c|}{ Corporate governance index for pension unit return and $\mathrm{ROA}$} \\
\hline \multirow[t]{2}{*}{ CG index } & $-0.004^{*}$ & -0.021 & 0.075 & -0.065 & -0.003 & -0.048 & -0.015 & $-0.142^{*}$ & 0.031 & 0.028 \\
\hline & $(0.002)$ & $(0.028)$ & $(0.192)$ & $(0.048)$ & $(0.002)$ & $(0.044)$ & $(0.160)$ & $(0.068)$ & $(0.026)$ & $(0.022)$ \\
\hline \multicolumn{11}{|c|}{ Corporate governance index for pension unit return and DOA } \\
\hline \multirow[t]{2}{*}{ CG index } & -0.000 & 0.016 & 0.134 & 0.056 & -0.001 & 0.004 & $0.250^{* *}$ & 0.060 & 0.015 & 0.012 \\
\hline & $(0.002)$ & $(0.026)$ & $(0.131)$ & $(0.054)$ & $(0.002)$ & $(0.048)$ & $(0.104)$ & $(0.057)$ & $(0.023)$ & $(0.020)$ \\
\hline \multicolumn{11}{|c|}{ Corporate governance index for ROA and DOA } \\
\hline \multirow[t]{2}{*}{ CG index } & -0.004 & -0.035 & 0.063 & 0.001 & $-0.003^{*}$ & -0.012 & 0.356 & 0.005 & -0.017 & -0.014 \\
\hline & $(0.003)$ & $(0.035)$ & $(0.166)$ & $(0.057)$ & $(0.002)$ & $(0.047)$ & $(0.248)$ & $(0.086)$ & $(0.027)$ & $(0.023)$ \\
\hline \multicolumn{11}{|c|}{ Includes control variables assets and members } \\
\hline Obs. & 194 & 180 & 188 & 188 & 194 & 180 & 188 & 188 & 118 & 118 \\
\hline Firms & 21 & 17 & 21 & 21 & 21 & 17 & 21 & 21 & 16 & 16 \\
\hline
\end{tabular}

Note: Regressions are run by OLS, and the fixed-effects model, and the Tobit model. Variables definitions are in Table 1. OLS specifications include firm fixed effects and all specifications include year dummies. Robust standard errors are reported in parentheses. ${ }^{* *},{ }^{* *}$ and ${ }^{*}$ indicate significance at 1,5, and 10 percent levels, respectively.

\section{Conclusion}

This study investigates the association between governance and pension fund performance in Poland. The homogeneity of regulations among these funds and the access to data in all of them provides an excellent laboratory to examine the relationship between different governance factors and fund performance.

The results of the study confirm that the compensation system prevalent in the mutual fund industry, in which managers' profits are defined by the size of the funds, does not create an incentive to discipline managers in the pension fund market. Henceforth, internal governance mechanisms are assumed to be important, as they should substitute for the external mechanisms.

In line with predictions, and controlling for other factors, the results show a positive correlation between the number of outsiders on the board and the pension unit return. Moreover, the results suggest that other characteristics such as the age or the education of the board members or the Chairman may be important, 
too. On the contrary, those factors were often negatively and significantly related to the pension fund's profitability measured by ROA and ROA or to the two dividend payout ratios. Furthermore, other factors such as pension activism and behavior are found to be important in explaining the return and profitability of the pension funds. Lastly, a combination of the different governance mechanisms in an index that benchmarks factors that are important for both a fund's beneficiaries and its owners loses its power to predict the fund's performance.

What is more important, the study documents that the external and internal governance mechanisms in pension funds are currently weak, as the results show that turnover in management and board members is not related to the fund's performance. While changing external factors may be very difficult due to the lack of interests or knowledge of the members to monitor the pension fund's investment results, a greater emphasis should be put on internal mechanisms. Consequently, the study is important from a policy perspective as it suggests a way to improve the performance of pension funds, whereas the results confirm that board composition may play an important role.

In other words, governments as well as supervisors should consider a more active role in the selection process of the board members, while reducing their choices to professional beneficiaries of the pension funds. On the other hand, this selection process should also take into account the interests of the owners, who provide the capital but are not carrying the risk in DC pension funds. A board dominated only by trustees may discourage further investments in the industry, which could negatively affect market competitiveness.

Nevertheless, more research is needed in order to reveal and confirm the impact of the different governance factors, using different institutional frameworks and methodologies to address the potential endogeneity concerns between governance measures and performance. However, I leave these questions and problems for future research.

\section{References}

Adams, J. C., Mansi, S. A., and Nishikawa, T. (2010). Internal governance mechanisms and operational performance: Evidence from index mutual funds. Review of Financial Studies 23(3), 1261-1286.
Andrews, E. S. (2006). Pension reform and the development of pension systems: An evaluation of World Bank assistance. Washington, DC: World Bank Publications.

Agrawal, A., and Knoeber, C.R. (2001). Do some outside directors play a political role? Journal of Law and Economics 44, 179-198.

Antolín, P., and Stewart, F. (2009). Private pensions and policy responses to the financial and economic crisis. OECD Working Papers on Insurance and Private Pensions No. 36. OECD publishing, (c) OECD. doi:10.1787/224386871887

Bhagat, S., Bolton, B. and Romano R. (2008). The promise and peril of corporate governance indices. Columbia Law Review 108(8), 1803-1882.

Bebchuk, L., and Cohen, A. (2005). The costs of entrenched boards. Journal of Financial Economics 78, 409-433.

Bebchuk, L. A., and Weisbach, M. S. (2010). The state of corporate governance research. Review of Financial Studies 23(3), 939-961.

Becht, M., Bolton, P., and Röell, A. A. (2002). Corporate governance and control. ECGI - Finance Working Paper No. 02/2002. Available at SSRN: http:// ssrn.com/abstract $=343461$ or $\mathrm{http}: / / \mathrm{dx}$.doi. org/10.2139/ssrn.343461

Berger, A. N., Clarke, G. R., Udell, G. F., Cull, R., and Klapper, L. F. (2005). Corporate governance and bank performance: A Joint Analysis of the Static, Selection, and Dynamic Effects of Domestic, Foreign, and State Ownership. World Bank Policy Research Paper No. 3632. Available at SSRN: http://ssrn.com/abstract $=756948$

Besley, T., and Prat, A. (2003). Pension fund governance and the choice between defined benefit and defined contribution plans. CEPR Discussion Paper No. 3955.

Brown, L. D., and Caylor, M. L. (2004). Corporate governance and firm performance. Available at SSRN: $\underline{\text { http://ssrn.com/abstract }=586423}$.

Carter, D. A., Simkins, B. J., and Simpson, W. G. (2003). Corporate governance, board diversity, and firm value. Financial Review 38, 33-53.

Casterella, J., Knechel, W. R., and Walker, P. L. (2004). The relationship of audit failures and auditor tenure. Proceedings, University of Kansas Auditing Symposium, May. 
Chen, G., Firth, M., Gao, D. N., and Rui, O. M., (2006). Ownership structure, corporate governance, and fraud: Evidence from China, Journal of Corporate Finance 12, 424-448.

Core, J., Holthausen, R., and Larcker, D. (1999). Corporate governance, chief executive officer compensation, and firm performance. Journal of Financial Economics 51(3), 371-406.

Cronqvist, H., and Thaler, R. (2004). Design choices in privatized social security systems: Learning from the Swedish experience. American Economic Review Papers and Proceedings 94, 424-428.

Daines, R., Gow, I. D., and Larcker, D. F. (2010). Rating the ratings: How good are commercial governance ratings? Journal of Financial Economics 98(3), 439-461.

Denis, D. J., and Denis, D. K. (1995). Performance changes following top management dismissals. Journal of Finance 50, 1029-1057.

Davis, L. R., Soo, B., and Trompeter, G. (2003). Auditor tenure, auditor independence and earnings management. Working Paper, Boston College. Boston, MA.

Faccio, M. (2006). Politically-connected firms. American Economic Review 96, 369-386.

Ferris, S. P., Jagannathan, M., and Pritchard, A.C. (2003). Too busy to mind the business? Monitoring by directors with multiple board appointments. Journal of Finance 58, 1087-1111.

Francis, J. R. (2004). What do we know about audit quality? British Accounting Review 34, 345-368.

Franks, J. R., Mayer, C., and Renneboog, L. (2001). Who disciplines management in poorly performing companies? Journal of Financial Intermediation 10, 209-248.

Gillan, S. L., Hartzell, J. C., and Starks, L. T. (2006). Tradeoffs in corporate governance: Evidence from board structures and charter provisions. Available at SSRN: http://ssrn.com/abstract=917544.

Gompers, P. A., Ishii, J. L., and Metrick, A. (2003). Corporate governance and equity prices. Quarterly Journal of Economics 118(1), 107-155.

Guercio Del, D. and Hawkins, J. (1999). The motivation and impact of pension fund activism. Journal of Financial Economics 52, 293-340.

Gugler, K. and Yurtoglu, B. B. (2003). Corporate governance and dividend pay-out policy in
Germany. European Economic Review 47, 731758.

Jensen, M. C. (1993). The modern industrial revolution, exit, and the failure of internal control systems. Journal of Finance 48, 831-880.

Jenter, D., and Lewellen, K. (2010). Performanceinduced CEO Turnover. Working Paper, Stanford University. Available at: http://areas.kenanflagler.unc.edu/finance/JHfinance/Documents/ Lenter $1 \quad 18 \quad 10 \quad$ CEO \%20turnover\%20 Jackson\%20Hole.pdf

Kaplan, S. (1994). Top executive rewards and firm performance: A comparison of Japan and the US. Journal of Political Economy 102, 510-546.

Kaplan, S. N., and Minton, B. A. (1994). Appointments of outsiders to Japanese boards: Determinants and implications for managers, Journal of Financial Economics 36(2), 225-258.

Karpoff, J. M., and Lott Jr., J. R. (1993). The reputational penalty firms bear from committing criminal fraud. Journal of Law and Economics 36, 757802.

Kim, H., and Lim, C. (2010). Diversity, outside directors and firm valuation: Korean evidence, Journal of Business Research 63(3), 284-291.

Kominek, Z. (2006) Regulatory induced herding? Evidence from Polish pension funds. European Bank for Reconstruction and Development, Working Paper No. 96. Available at: http://www. ebrd.com/downloads/research/economics/ workingpapers/wp0096.pdf

Kowalewski, O. (2008), Social services in Poland: The pension system. In M. A. Weresa (ed.), Poland competitiveness report 2008. Focus on services. Warsaw: WSE Publishing House.

Kowalewski, O., Stetsyuk, I., and Talavera, O. (2008). Does corporate governance determine dividend payouts in Poland? Post-Communist Economies 20(2), 203-218.

Lean, D. F., Ogur, J. D. and Rodgers, R. P. (1985). Does collusion pay... does antitrust work. Southern Economic Journal 51, 828-839.

Masulis, R. W., Wang, C., and Xie, F., (2010) Globalizing the boardroom - the effects of foreign directors on corporate governance and firm performance. AFA 2011 Denver Meetings Paper. Available at SSRN: http://ssrn.com/abstract=1572838. 
Monks, R. A. G., and Minow N. (1991). Power and accountability. Dunmore, PA: HarperCollins.

Myners Report (2001). Institutional Investment in the UK: A Review. London, UK: HM Treasury

Netter, J. M., Poulsen, A. B., and Stegemoller, M. A. (2009). The rise of corporate governance in corporate control research. Journal of Corporate Finance 15(1), 1-9.

Park, Y. W. and Shin, H. H. (2004). Board composition and earnings management in Canada, Journal of Corporate Finance 10, 431-457.

Rudolph, H., Hinz, R., Antolín, P., and Yermo, J. (2010). Evaluating the financial performance of pension funds. In R. Hinz, H.P. Rudolph, P. Antolín, and J. Yermo, (eds.), Evaluating the Financial Performance of Pension Funds. (Chapter 1). Washington, DC: The World Bank.

Skantz, T. R., Cloninger, D. O., and Strickland, T. H. (1990). Price-fixing and shareholder returns: an empirical study. Financial Review 25, 153-164.

Sirri, E. and Tufano, P. (1998). Costly search and mutual fund flows, Journal of Finance 53, 1589-1622.

Tapia, W. (2008). Comparing aggregate investment returns in privately managed pension funds: An initial assessment. OECD Working Papers on Insurance and Private Pensions No. 21. OECD publishing, doi:10.1787/237833258822. Available at: http://www.oecd.org/dataoecd/39/5/41408063.pdf

Vafeas, N. (2003). Length of board tenure and outside director independence. Journal of Business Finance and Accounting 30, 1043-1064.

Warner, J. B., Watts R. L., and Wruck, K. H. (1988). Stock prices and top management changes, Journal of Financial Economics 20, 461-492.

World Bank (1994). Averting the old age crisis. Policies to protect the old and promote growth. New York, NY: Oxford University Press.

Yermack, D. (1996). Higher market valuation of companies with a small board of directors. Journal of Financial Economics 40(2), 185-211.

\section{Notes}

1 Extreme examples are Argentina and Bolivia, who nationalized their private pension funds in 2008 and 2010, respectively. In 2010, the governments of Hungary and Poland were proposing the nationalization of private pension funds, while
Bulgaria delayed the plans to reform its pension system toward private funds.

2 See Shleifer and Vishny (1997), Becht et al. (2002), Bebchuk and Weisback (2010) and Netter et al. (2009) for a literature survey on corporate governance.

3 GovernanceMetrics, a leading corporate governance rating agency, does not classify directors as independent that are nominated by an entity whose voting interest in the company exceeds 5\%.

4 In 2010, the Polish government proposed a bill that would forbid the changing of the pension funds.

5 The results are available upon request. 